Rosângela Suetugo Chao

\title{
Odontogênese: construção e validação de um objeto de aprendizagem inovador
}

Dissertação apresentada à Faculdade de Medicina da Universidade de São Paulo para obtenção do título de Mestre em Ciências

Programa de Ciência Médicas

Área de concentração: Educação e Saúde

Orientadora: Profa. Dra. Patrícia Zen Tempski

São Paulo 


\section{Dados Internacionais de Catalogação na Publicação (CIP)}

Preparada pela Biblioteca da

Faculdade de Medicina da Universidade de São Paulo

Creprodução autorizada pelo autor

\section{Chao, Rosângela Suetugo}

Odontogênese : construção e validação de um objeto de aprendizagem inovador / Rosângela Suetugo Chao. -- São Paulo, 2017.

Dissertação(mestrado)--Faculdade de Medicina da Universidade de São Paulo. Programa de Ciências Médicas. Área de Concentração: Educação e Saúde. Orientadora: Patrícia Zen Tempski.

Descritores: 1.Materiais de estudo 2.Imagem tridimensional 3.Odontogênese 4.Tecnologia educacional 5.Educação em odontologia 6.Comunicação em saúde 7.Telemedicina

USP/FM/DBD-362/17 
Dedica esse trabalho aos entes muita valiosos do meu coraçãa!

Aa meu pai Kazuyuki (in memoriam) e minha mäe Sumika amores e gratidãa eternos por terem me dado as bases fundamentais de amor, familia, educaçãa, caráter e generasidade,

Ao meu marida Cha Lung Wen, amor da minha vida e que me ajuda a aprimorar essas bases

As minhas filhas Mairra e Mariana, joias que amo de paixãa. frutas do meu aprimaramenta! 


\section{AGRADECIMENTOS}

À Deus pela felicidade que dá ao meu coração; por ter me concedido esse tempo da minha vida para realização desse trabalho; colocado pessoas maravilhosas no meu caminho para que eu pudesse aprender e enriquecer ainda mais o meu saber... a sorte de ter encontrado grandes educadores, mestres, professores, grandes pessoas, humanas e inspiradoras no meu caminho

À minha orientadora Profa. Dra. Patricia Tempski que acreditou em mim, e sempre ao meu lado fez com que minha aprendizagem se transformasse em uma experiência maravilhosa marcando minha vida de tal forma que a tenho como minha irmã de coração.

Ao Prof. Dr. Chao Lung Wen que tenho enorme admiração e gratidão pela sua generosidade, seu jeito para educar é ímpar transformando nossa mente e não mediu esforços para realização desse trabalho.

Ao Prof. Dr. Victor Arana não tenho palavras significativas que me permitam expressar a imensa gratidão pelo que aprendi e pelas inúmeras vezes que disponibilizou seu tempo para discutir e construir a odontogênese.

Ao Prof. Dr. Milton de Arruda Martins que generosamente concedeu-me a oportunidade de realizar minha dissertação na Clínica Medica.

Aos professores Dra. Ana Estela Haddad e Dr. Marcelo Bonecker, pela oportunidade de aprender com a equipe da teleodontopediatria, experiência valiosíssima.

Ao Prof Dr. Wu Tu Hsing meu grande amigo, professor e incentivador, que me ensinou a maravilhosa especialidade que é a acupuntura.

Ao Prof György Böhm que está disponível para todas as dificuldades, pela nossa grande amizade e conselhos, permitiu-me a realização desse trabalho.

À equipe da Telemedicina, Gustavo, Caroline, Angelo, Helena Micheline, Diogo Ana, Fabio, Marcelo, Eglen Mari, Thiago, Adriano, Maira, Marcia e 
Zenaide, agradeço de coração todos vocês por possibilitar a construção gráfica e tecnológica desse trabalho.

À Profa. Dra. Fernanda Brenneisen Mayer pelo acolhimento e ensinamentos que recebi desde o primeiro dia de mestrado até o final da dissertação, uma grande amiga.

À Profa. Dra. Renata Kobayashi pela imensa ajuda nas estatísticas, uma pessoa muito iluminada, sempre pronta a ajudar.

À Profa. Dra. Silvia Enns, Profa. Dra. Fernanda Arantes, Prof. Dr. Paulo Silveira e colegas da pós-graduação Dra. Silvia Nigro, Cristiane Goncalves Mota, Estefania Lima, Luciana Tavares; por contribuírem no meu aprendizado, ajudarem no piloto, por me apresentar o Mendeley,

Aos Profs. da qualificação Profa. Dra. Lucia Garcia, Profa Dra. Iolanda de Fátima Lopes Calvo Tiberio, Prof. Dr. Wagner de Oliveira pelas valiosas sugestões.

Às professoras e professor que participaram na validação, contribuindo para o aperfeiçoamento desse trabalho.

À Prof. Dra. Marise Sano Suga Matumoto minha querida irmã e amiga presença constante em minha vida.

Aos meus genros Istvan Horvath e Leandro Yamada pelo carinho e respeito.

Ao meu neto querido Victor Horvath que é a minha alegria e felicidade.

Ao meu irmão Paulo, minha cunhada Cristina e meus sobrinhos Thais, Gustavo e Filipe Suetugo incentivos e presença constante na minha vida

Meu sogro (in memoriam) Chao Chih Chun e minha sogra (in memoriam) Chao Cheng Tao pelo carinho, amor e respeito que me receberam em sua família. 
Minhas cunhadas e cunhado: Chao Su Yi, Sueli e Chao Lung Chih e meus sobrinhos Marcelo, Dhavi e Dhebora Chao. 
"A esperança é que a educaçãa através dos recursos da tecnologia digital e da prática educacional a distância estimule as nossos professores a dominar as nouss métados didáticas que abrem um menda nova na pedagagia. Um munda que nãa tem fronteiras $e$. mais ceda ou mais tarde, acordarãa para a inwasãa de programas alienégenas na campa de suas especialidades. Serãa desafiados para construérem seus programas, coma famos no casa das liuras, apenas que se trata de um fenomena de alta velacidade. Os estudantes serãa os juizes: a eles e elas caberá decidir qual ferramenta oferece melhor aprendizada. É minha canvicçãa que as professares respanderãa na medida em que se interessarem pela tecnologia educacional e souberem ensinar $e$ aualiar com as recursos à sua dispasiçãa".

\section{György Miklás Böhm}




\section{RESUMO}

Chao RS. Odontogênese: construção e validação de um objeto de aprendizagem inovador [dissertação]. São Paulo: Faculdade de Medicina, Universidade de São Paulo; 2017.

Introdução: Há uma demanda social de produção de material educacional interativo, flexível e visualmente atrativo; que tenha fácil acesso, comunicação e veiculação por meio das mídias e da internet, e principalmente que possibilite a difusão do conhecimento. Objetivos: $O$ presente estudo teve como objetivos a construção e validação de objeto de aprendizagem com uso de computação gráfica 3D sobre odontogênese. Método: Baseou-se nos princípios da educação de adultos e na aprendizagem significativa. A construção do objeto de aprendizagem partiu da revisão da literatura e da discussão com grupo de especialistas multiprofissional. A partir destes dados, foi construído um roteiro baseado em uma matriz de objetivos educacionais. Este roteiro direcionou uma produção intelectual em formato de vídeo. Para a validação dessa produção intelectual, foi construído um processo de revisão por pares com análise crítica e sistematizada aplicada a um conjunto de 22 professores e profissionais de expertise reconhecida na área e atuantes em várias universidades distribuídas pelo território brasileiro. Resultados: $O$ objeto de aprendizagem sobre odontogênese incluiu um vídeo elaborado a partir da tecnologia de computação gráfica 3D e narração, com nove minutos de duração. A análise das respostas do grupo de validadores mostrou unanimidade de visão positiva em vários itens do instrumento de validação destacando as afirmativas relacionadas aos movimentos das cenas, entendimento de todas as fases da odontogênese, assim como o uso de imagens tridimensionais e animação auxiliaram o entendimento e aprendizado do tema. Foi considerada uma ferramenta útil para a prática, por trazer uma síntese de informações, condensando conceitos relevantes apresentados de forma dinâmica com propósito educacional. Além disto, foi considerado um objeto de aprendizado flexível por atender a diversos interesses de aprendizado, sendo adaptável a diferentes públicos e objetivos, podendo contribuir com a formação de estudantes, pós-graduandos e profissionais da área de saúde. Conclusão: O processo de validação contribui 
para o aprimoramento do objeto de aprendizagem considerado adequado, útil, inovador e flexível. De acordo com os validadores, ter contato com essa tecnologia durante suas graduações, teria facilitado o entendimento sobre odontogênese.

Descritores: materiais de estudo; imagem tridimensional; odontogênese; tecnologia educacional; educação em odontologia; comunicação em saúde; telemedicina 
Chao RS. Odontogenesis: construction and validation of an innovative learning object [dissertation]. São Paulo: "Faculdade de Medicina, Universidade de São Paulo"; 2017.

Introduction: There is a social demand for the production of an interactive educational material, which is flexible and visual attractive; that has an easy access, communication, media and internet placement and primarily that makes the diffusion of knowledge possible. Objective: The aim of this study was the construction and validation of a learning object with the use of 3D computer graphics about odontogenesis. Method: It was based on adults' education principals and on the significant learning. The construction of the learning object started on the literature review and the discussion with a group of multiprofessional specialists. From these data it was constructed a script based on an educational objectives matrix. This script has directed to an intellectual production in a video format. For the validation of this intellectual production, it was built a pair review process with a critical and systematized analysis applied to a set of 22 professors with expertise in the area and active in several universities distributed in the Brazilian territory. Results: The learning object about odontogenesis resulted a nine minute video elaborated with narration and 3D computer graphics technology. The analysis of the group of validators' answers showed a positive view unanimity in several items of the validation instrument, highlighting the affirmations related to the movements of the scenes, understanding of all phases of odontogenesis, as well as the use of threedimensional images and animation that assisted the understanding and learning of the theme. It was considered a useful tool for the practice for bringing a synthesis of information, condensing relevant concepts presented dynamically for educational purposes. Furthermore, it was considered a flexible learning object for attending various learning interests, being adaptable to different publics and objectives; it could contribute with potenciality to undergraduate, for the learning of postgraduate students and health professionals. Conclusion: The validation process contributed to the improvement of the learning object that was considered adequate, useful, innovative and flexible. According to the validators, 
having contact with this technology during their graduation course would have facilitated odontogenesis understanding.

Descriptors: study materials; imaging, three-dimensional; odontogenesis; educational technology; education, dental; health communication; telemedicine 


\section{LISTA DE QUADROS}

Quadro 1 - Marcos do Desenvolvimento Dental .22

Quadro 2 - Matriz de objetivos e competências .28 


\section{LISTA DE FIGURAS}

Figura 1 - Passo 1: Modelagem - processo de modelagem poligonal em software 3D. 30 .

Figura 2 - Passo 2: Animação - processo de animar uma câmera ou objeto...31

Figura 3 - Passo 3: Texturização - processo de aplicação de material com informação de cor, textura, rugosidade e brilho 32

Figura 4 - Passo 4: lluminação - processo de aplicar diferentes tipos de luzes para iluminar a cena.

Figura 5 - Passo 5: Renderização - processo de render transforma a cena criada e animada em vários frames ou fotos. 35

Figura 6 - Plataforma interativa de aprendizagem Nuvem do Conhecimento .37

Figura 7 - Fluxograma de participantes e perdas do estudo .41

Figura 8 - Distribuição do grupo de validadores por instituição de ensino. .42

Figura 9 - Análise de item das afirmativas 1 a 6 (CT, concordo totalmente; C, concordo; I, indiferente; D, discordo; DT, discordo totalmente). .44 
Figura 10 - Análise de item das afirmativas 7 a 12 (CT, concordo totalmente; C, concordo; I, indiferente; D, discordo; DT, discordo totalmente) 45

Figura 11 - Análise de item das afirmativas 13 a 18 (CT, concordo totalmente; C, concordo; I, indiferente; D, discordo; DT, discordo totalmente). 46

Figura 12 - Análise de item das afirmativas 19 a 24 (CT, concordo totalmente; C, concordo; I, indiferente; D, discordo; DT, discordo totalmente) .47

Figura 13 - Análise de item das afirmativas 25 a 30 (CT, concordo totalmente;

C, concordo; I, indiferente; D, discordo; DT, discordo totalmente) .48

Figura 14 - Análise de item das afirmativas 31 a 36 (CT, concordo totalmente; C, concordo; I, indiferente; D, discordo; DT, discordo totalmente). .49

Figura 15 - Análise de item das afirmativas 37 a 39 (CT, concordo totalmente; C, concordo; I, indiferente; D, discordo; DT, discordo totalmente). .50

Figura 16 - Análise das respostas de zero a dez para conteúdo; design e imagens; apresentação e layout; computação gráfica 3D e animação. .56

Figura 17 - Análise das respostas de zero a dez para som; narração e por fim roteiro 57 


\section{LISTA DE TABELAS}

Tabela 1 - Análise de resposta por frequência .51

Tabela 2 - Análise da percepção positiva e negativa dos validadores de acordo com suas respostas ao questionário de validação do objeto de aprendizagem..53

Tabela 3 - Notas de zero a dez atribuídas ao objeto de aprendizagem de acordo com as sete variáveis. 58

Tabela 4 - Análise qualitativa das respostas acerca de forças do material didático .60

Tabela 5 - Análise qualitativa das respostas acerca de fraquezas do material didático 61 


\section{SUMÁRIO}

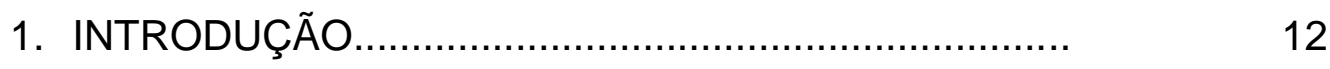

1.1 Tecnologia educacional.................................. 12

1.2 Andragogia.............................................

1.3 Odontogênese............................................... 19

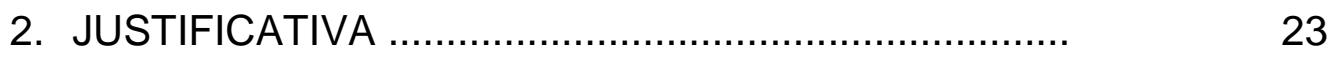

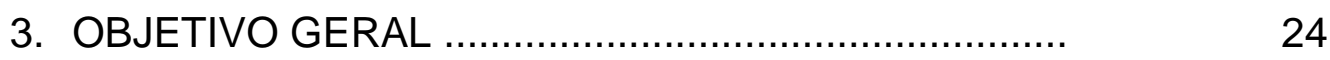

3.1 Objetivos específicos......................................

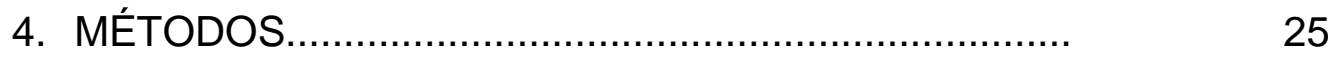

4.1 Construção do objeto de aprendizagem sobre odontogênese ...................................................... 26

4.2 Validação do objeto de aprendizagem sobre a odontogênese.................................................. 35

4.3 Análise dos dados.......................................... 38

5. RESULTADOS ….............................................

5.1 Objeto de Aprendizagem............................ 40

5.2 Processo de validação do objeto de aprendizagem 41

5.2.1 Amostra dos participantes......................... 41

5.2.2 Análise dos dados quantitativo..................... 43

5.2.3 Análise dos dados qualitativos................... 59 


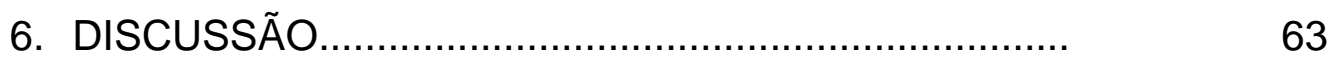

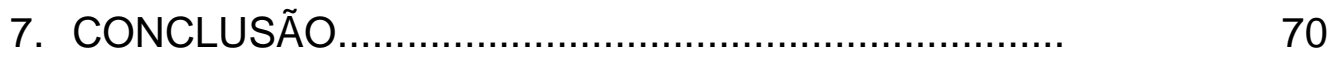

8. REFERÊNCIAS ............................................ 71

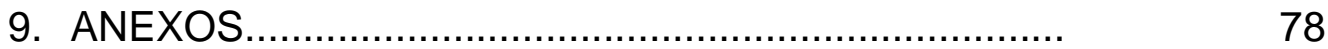




\section{INTRODUÇÃO}

\subsection{Tecnologia Educacional}

Estamos vivenciando uma revolução tecnológica que abrange as áreas da eletrônica, das telecomunicações, da computação e da educação. São exemplos desta revolução tecnológica: a Internet; a rede de telefonia móvel, representada pelos aparelhos de telefone celular e smartphones integrados a diversos dispositivos, inclusive aos televisores digitais; os modernos notebooks/netbooks e as mais recentes pranchetas eletrônicas com recursos de conectividade por celular 4G. E não podemos deixar de citar a integração destas tecnologias com a computação gráfica e realidade virtual (1). Neste contexto, a evolução dos recursos computacionais aumentou a capacidade de processamento dos dispositivos, suas características gráficas e interativas, ao mesmo tempo em que houve uma grande redução dos custos, permitindo maior acessibilidade à grande parte da população (2).

Além da acessibilidade, a tecnologia possibilitou o desenvolvimento de soluções mais seguras e interativas de transmissão de dados e a criação de novas formas de colaboração e aprendizado que não eram possíveis com os métodos convencionais. A socialização do conhecimento atualmente se dá em um processo dinâmico que envolve diferentes mídias, representações da informação e utilização das mais variadas tecnologias, atendendo a diversidade cultural das diferentes gerações. As tecnologias interativas aplicadas à educação permitem ampliar a pluralidade de abordagens educacionais e atender a diferentes estilos de aprendizagem, além de otimizar tempo e recursos na construção do conhecimento, que como processo histórico envolve diferentes gerações, mídias e representações da informação. Trata-se de um processo dinâmico no qual as pessoas, a todo o momento, estão construindo, criando e recriando novos signos imersos nas mais diversas tecnologias $(3,4)$.

Essa realidade teve impacto na área educacional e tem alterado significativamente as formas de interação na nossa sociedade, principalmente na população mais jovem. Nesse sentido, os mais jovens, que já nasceram 
inseridos nessas tecnologias, têm mais facilidade com a apreensão do funcionamento e aplicação delas. São chamados de nativos digitais, termo esse introduzido pelo consultor de educação Marc Prensky(5), em 2001. Segundo Prensky, as crianças nascidas a partir de 1980, criadas em um mundo digital saturado de mídia, têm uma forma de pensar e processar a informação diferente; elas obtêm as informações de forma rápida, recorrendo a fontes digitais e à internet, interagindo em diversas mídias ao mesmo tempo ${ }^{(6)}$.

O uso da tecnologia na educação cresceu e se consolidou no mundo e no Brasil nesta última década devido à evolução da eletrônica, da telecomunicação e da computação. Nesse sentido, a educação como processo permanente ocorre em variados espaços e situações sociais, incluindo o espaço virtual, sendo compreendida como um dos principais fatores de promoção humana e social $(2,7)$. Apesar de ser possível se aprender por diversos meios, determinados fatores propiciam uma maior aprendizagem e retenção do conhecimento. As pessoas aprendem coisas diferentes, em diferentes tempos e por diferentes razões ${ }^{(8)}$.

A educação no século XXI tem suas coordenadas apoiadas em evidências de que a comunicação deve estar adequada à cultura dos educandos. Tão rápido quanto as novas tecnologias, os processos de comunicação em educação vêm se reciclando para atingir uma nova geração, mais informada, mais exigente e em contato permanente com todo o mundo, em tempo real. Esse novo profissional, estudante e a população querem participar, descobrir e opinar sobre o que aprendem. Nesse novo contexto, os meios de comunicação passam a fazer parte de uma grande convergência de mídias, que reveza o papel de protagonista entre a TV, o rádio, a Internet e até as telefonias móveis (smartphones e Tablets), de acordo com o que e como se pretende ensinar (9). Os recursos oferecidos pelas novas tecnologias podem ainda favorecer a aprendizagem independente, trazer motivação e compensar inibições ${ }^{(10)}$

A internet proporcionou novas formas de comunicação entre as pessoas e em última análise também novas formas de educar como, por exemplo, a teleducação interativa ${ }^{(11,12) .}$ A teleducação interativa é a educação mediada por tecnologia que amplia a possibilidade de construção de conhecimentos por meio das facilidades de acesso a materiais educacionais, possibilitando replicar a 
educação mesmo para localidades fisicamente distantes, podendo nestes casos utilizar os ambientes virtuais (4).

Dentre as vantagens comumente relatadas ao se usar um ambiente virtual de aprendizagem, podemos citar a facilidade de atualização do material; acesso ao material a partir de locais diferentes; restrição de acesso somente a alunos inscritos; possibilidade de pesquisar em outros sites de informações; incorporação de material multimídia; possibilidade de participar do curso por menor custo; viabilidade de utilizar simultaneamente os diversos recursos educacionais e aumentar as chances de interação entre participantes com 0 professor. Além da facilidade de acesso ao professor, as ferramentas de educação a distância podem reduzir as inibições dos alunos em relação às participações presenciais, considerando a privacidade e a possibilidade de formulação de perguntas após reflexão ${ }^{(13)}$.

O cenário virtual permite aos professores e alunos participarem de um processo conjunto que favorece o aprendizado de forma criativa, dinâmica, encorajadora, que tem como essência o diálogo e a descoberta, e se aplica aos diferentes níveis de formação, desde o ensino fundamental a pós-graduação (2).

$\mathrm{Na}$ formação de graduação em Odontologia, essas mudanças são estimuladas pelas Diretrizes Curriculares Nacionais homologadas em 2002, pelo Conselho Nacional de Educação. Elas descrevem como uma competência do egresso a habilidade de acompanhar e incorporar o uso de inovações tecnológicas como, por exemplo, a informática ${ }^{(14)}$.

As possibilidades educacionais na era da informática ampliam a formação do cirurgião-dentista e apontam para a necessidade da reformulação curricular dos cursos de graduação de odontologia, de forma a aprimorar o processo de ensino e aprendizagem por meio de ferramentas digitais como tablets e smartphones. Outros exemplos são os livros digitais "ebooks" e os "audiobooks" transmitidos e compartilhados pela da Internet ${ }^{(15)}$.

A eficiência do processo educacional pode ser potencializada com o uso das tecnologias digitais. Elas podem apoiar a construção de componentes interativos que auxiliem professores a explicar e os alunos a compreender a 
anatomia e função dos diferentes órgãos e sistemas. Podemos citar como exemplo o Projeto Homem Virtual (www.projetohomemvirtual.org.br), que utiliza os recursos da comunicação visual por meio da computação gráfica 3D para transmitir conhecimentos de forma visual e dinâmica. Por serem unidades flexíveis e utilizáveis de diferentes formas pelos educadores, as sequências do Homem Virtual são designadas como "Objetos de Aprendizagem" (10,16).

Compreende-se por objeto de aprendizagem qualquer material digital (textos, animações, vídeos, imagens, aplicações, páginas Web em comunicação, computação gráficas 3D) que se destine a apoiar o aluno no processo de aprendizagem. São recursos digitais reutilizáveis visando a apoiar a aprendizagem presencial e a distância $(17,18)$.

Uma das principais características de um objeto de aprendizagem é sua flexibilidade de utilização, ou seja, uma vez adaptado, ele pode ser reutilizado em diversos ambientes de aprendizagem (19,20).

Analogamente, podemos representar o objeto de aprendizagem como peças do brinquedo "LEGO", que podem ser combinados de diversas maneiras e formatos capazes de ofertar estratégias de aprendizagem diversificadas e ajustadas às necessidades dos estudantes ${ }^{(21,22)}$.

A produção de materiais educacionais digitais na forma de objetos de aprendizagem tem sido uma alternativa para a apresentação de conteúdos de forma dinâmica e interativa ${ }^{(21,23)}$.

A educação na área saúde incorporou a tecnologia digital ao método tradicional de ensino, no entanto ainda existem temáticas pouco abordadas como, por exemplo, na área odontológica, a odontogênese. Este projeto de pesquisa visa à construção e validação de Objetos de Aprendizagem sobre o processo da formação dental - odontogênese, que potencialmente contribua para a formação de estudantes e profissionais da área da saúde. 


\subsection{Andragogia}

O paradigma tradicional da educação se baseia na transmissão de conhecimento pelo professor, na memorização dos alunos e aplicação deste conhecimento em teste. O paradigma emergente exige conexões e interrelações dos agentes envolvidos (professor e aluno) no processo de ensinar e de aprender pautados na autonomia de buscar construir conhecimentos de forma colaborativa ${ }^{(24) \text {. }}$

Malcolm Knowles, educador americano, que estudou a teoria da aprendizagem dos adultos, é considerado o pai da andragogia. Esse termo é derivado das palavras gregas: Anner, Andrós: homem e Agogus, Agogè: ação de conduzir. Segundo Knowles, andragogia é a arte ou ciência de orientar adultos a aprender (25).

A andragogia possui algumas características. Uma delas é a necessidade de aprender, isto é, os adultos aprendem quando reconhecem que precisam aprender e entendem o valor do novo conhecimento. Para o adulto, suas experiências são a base de seu aprendizado (26). Outra característica é a autonomia, ou seja, os adultos são responsáveis por suas decisões e por sua vida, portanto, querem ser vistos e tratados pelos outros como capazes de se autodirigir. Eles devem ter uma expectativa razoável de que o conhecimento que eles ganham os ajudará a alcançar seus objetivos. Estão dispostos a aprender quando o conteúdo parece estar relacionado a situações reais, ou seja, quando o conhecimento tem a finalidade de ajudá-los a enfrentar os desafios cotidianos (27).

Os adultos aprendem melhor quando há uma orientação para aprendizagem e os conceitos são apresentados de modo contextualizado, orientados para os fatos, aplicabilidade e resultados (27). A aprendizagem se potencializa quando as atividades têm como eixo orientador situações reais e respondem bem quando fatores motivacionais entram em cena como, por exemplo, satisfação, qualidade de vida e autoestima (63).

Ainda nesta lógica de considerar as vivências prévias, se coloca o conceito de aprendizagem significativa (28). A aprendizagem significativa é 
definida como a interação entre um novo conhecimento ancorado a estruturas do conhecimento antigo, ou seja, para que ocorra a aprendizagem significativa o conteúdo ensinado deve ser relacionável com a estrutura cognitiva do aluno e de conceitos relevantes que possibilitem a sua conexão com a nova informação a ser aprendida, de modo que ela adquira assim um significado para o indivíduo (29). O conhecimento que se adquire de maneira significativa é armazenado e lembrado por mais tempo, além de aumentar a capacidade de aprender outros conteúdos com maior facilidade ${ }^{(26,30)}$.

A valorização das experiências anteriores do aluno no processo de aprendizagem também foi enfatizada por Paulo Freire, que considera que os recursos intelectuais e as experiências prévias relevantes de cada pessoa constituem pontos de referências para novas aprendizagens. $O$ autor também ressalta que os adultos querem saber pela necessidade de conhecer, e aprendem quando reconhecem essa necessidade (31).

Segundo Paulo Freire, o processo de ensino aprendizagem é uma interação social dialógica e dialética entre aquele que ensina, aquele que aprende e o objeto de aprendizagem. Aquele que forma, ao formar, se reforma, demonstrando o caráter transformador da educação para ambos professor e aluno ${ }^{(31)}$.

$\mathrm{O}$ advento da interconectividade com a internet e das redes de comunicação favoreceu mudanças profundas na educação presencial e a distância (2) que exigem que o professor assimile a cultura digital em constante evolução, uma vez que, como afirma Paulo Freire (31,32), ele é um mediador do conhecimento diante do aluno, que é o sujeito da sua própria formação. Neste processo, os alunos também mudaram, bem como suas necessidades. Esses estudantes estão acostumados a obter informações de forma rápida e costumam recorrer a fontes digitais e à Web antes mesmo de procurarem livros ou outra mídia impressa (22).

No novo paradigma da educação, cabe ao professor conhecer as demandas de aprendizagem dos seus alunos e as novas formas de ensinar e aprender. O professor deixa de ser um transmissor de saberes para converterse em formulador de problemas, coordenador de equipes de trabalhos, 
sistematizador de experiências que valoriza o diálogo e o aprendizado colaborativo ${ }^{(6)}$.

Outra mudança significativa na educação diz respeito às potencialidades do aprendizado em pares ou grupos, tanto no meio presencial como virtual, aos moldes das construções coletivas no formato Wiki, uma coleção baseada na web, escrita de maneira colaborativa, visitada e editada por qualquer pessoa.

O aprendizado colaborativo ou coaprendizagem foi descrito por Smith (33) para enfatizar a importância de mudar os papéis tanto dos professores, como distribuidores de conhecimento, quanto dos estudantes, de recipientes de conteúdos para 'coaprendizes'. Ou seja, parceiros no processo colaborativo de aprendizagem, na construção de significados, compreensão e criação de conhecimento em conjunto.

Esse processo colaborativo de aprendizagem tem propiciado acesso e construção de conhecimentos muito maior, além de contribuir para o surgimento de novas formas de aprender, consequência dos avanços tecnológicos extremamente acelerados, de um mundo digital, móvel, conectado, personalizado e de criações. É a era da educação 3.0 um termo que surgiu recentemente - Keats \& Schmicht ${ }^{(34)(2007)}$ - visando a ressaltar a importância de preparar todos os estudantes para Era Digital.

Este avanço tecnológico vai mais além da sala de aula, pois a educação tornou-se comunitária, virtual, multicultural e ecológica. A escola passa a ocupar diferentes espaços, saindo do tradicional espaço físico da sala de aula para ocupar outros espaços presenciais, virtuais e também espaços no mundo do trabalho, na comunidade, na cidade e no planeta ${ }^{(19)}$.

Os professores que seguem os princípios da andragogia e aplicam as novas tecnologias são mais bem-sucedidos em alcançar seus objetivos ${ }^{(30)}$. 


\subsection{Odontogênese}

A odontogênese é o processo de formação do dente, que começa nas primeiras semanas de vida intrauterina e continua durante anos após 0 nascimento ${ }^{(35)}$. No ser humano, este processo pode ser explicado destacandose os seguintes eventos:

- Fase de botão

- Fase de capuz

- Fase de campânula ou sino

- Fase da coroa

- Fase da raiz

Por volta da $4^{\text {a }}$ semana de desenvolvimento, células da crista neural migram para a região da face e pescoço formando seis arcos faríngeos, quatro visíveis externamente e dois rudimentares internos. $O$ primeiro arco origina $O$ processo maxilar e mandibular que delimita a cavidade bucal primitiva, 0 estomodeu. Superiormente, esta região é delimitada pelo processo frontal que também contribui para a formação do lábio e, na mesma fase, tem início o desenvolvimento da língua e dos componentes da cavidade bucal (36-38).

Na 5 semana, uma banda epitelial aprofunda-se no ectomesênquima, que é formado por células originadas na crista neural. Esta banda epitelial se divide em lâmina vestibular e lâmina dentária. A lâmina vestibular dará origem ao sulco vestibular, aos lábios e a bochecha; e a lâmina dentária dará origem ao arco dentário, onde ocorrerá a odontogênese ${ }^{(36-38)}$.

A odontogênese propriamente dita, começa por volta da $7^{\underline{a}}$ semana de vida intrauterina por influência das células que migraram da crista neural. Os dentes passam pelas mesmas fases de desenvolvimento, mas não ao mesmo tempo. Utilizaremos para este estudo, como referência cronológica, o incisivo central inferior decíduo ${ }^{(36)}$.

Na primeira fase de formação, chamada de botão, as células da lâmina dentária proliferam-se para dentro do ectomesênquima, criando uma saliência 
esférica, denominada de botão. Na $8^{a}$ semana, inicia-se a fase do capuz que se caracteriza pela condensação do ectomesênquima na porção inferior do botão. Esta condensação faz com que as bordas do botão se curvem, formando uma concavidade semelhante a um capuz. No interior do capuz, as células se diferenciam, formando o epitélio externo, epitélio interno e entre eles o retículo estrelado. Esse trio é chamado de órgão do esmalte, responsável pela formação do esmalte ${ }^{(36-38)}$.

As células ectomesenquimais abaixo do capuz se diferenciam em papila dentária, que formará a dentina e a polpa. O conjunto de órgão de esmalte mais a papila dentária é denominado de germe dentário. Ainda na fase do capuz, por meio da divisão e diferenciação de células ectomesenquimais, tem início a formação do processo alveolar, dos vasos sanguíneos e do folículo dentário. 0 folículo dentário no seu desenvolvimento envolve o germe dentário ${ }^{(36-38)}$.

A próxima fase é chamada de fase de campânula. É nela que a forma do dente é determinada. As células na região da futura cúspide param sua atividade mitótica; as demais continuam a dividir-se, originando uma força em direção a alça cervical que é o encontro dos epitélios interno e externo. A células do retículo estrelado se organizam em duas ou três camadas de células pavimentosas sobre o epitélio interno. Estas camadas são chamadas de estrato intermediário e também participam da formação do esmalte.

As células do epitélio interno emitem sinais para a lâmina basal. Estes sinais são percebidos pelas células ectomesenquimais da papila. Quando encostam na lâmina basal, diferenciam-se em odontoblastos e passam a secretar a primeira camada de dentina. A lâmina basal se degenera à medida que cumpriu a sua função de interface; por sua vez, as células do epitélio interno param sua divisão mitótica e aumentam seu conteúdo citoplasmático, graças ao desenvolvimento de organelas de síntese e secreção proteica. Tornam-se então alongadas com o núcleo próximo ao estrato intermediário. Esse fenômeno chama-se inversão de polaridade, e temos aí a sua diferenciação em ameloblastos, que iniciam a deposição de esmalte sobre a dentina (36-38). 
O prolongamento celular dos odontoblastos ficam aprisionados na matriz de dentina formando túbulos, muito próximos uns dos outros. A formação da dentina pelos odontoblastos é centrípeta e do esmalte pelos ameloblastos é centrífuga. Este estágio avançado da campânula é chamado de fase de coroa que se caracteriza pela deposição de dentina e esmalte. Ainda neste estágio, ocorre a desintegração da porção que liga o germe dentário à lâmina dentária e ao epitélio bucal ${ }^{(36,37)}$.

O folículo dentário passa a envolver todo o germe dentário. Em volta do folículo, forma-se a cripta óssea, e os capilares sanguíneos penetram na papila dentária. A formação do esmalte e da dentina começa na cúspide ou borda incisal e progride em direção à futura raiz. Quando a deposição de dentina e do esmalte alcança a região da alça cervical inicia-se a formação da raiz. As células dos epitélios interno e externo proliferam-se e formam uma dobra, originando 0 diafragma epitelial ${ }^{(36,37)}$.

A divisão celular continua dando origem a bainha epitelial radicular de Hertwig, que empurra as células do epitélio externo. Devido a defasagem de proliferação celular nesta região, a bainha de Hertwig fragmenta-se e origina os restos epiteliais de Malassez; na região da papila, os odontoblastos formam a

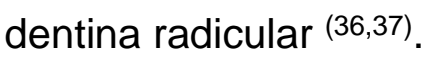

O folículo dentário nesta fase é responsável pela formação do cemento, do ligamento periodontal e do osso alveolar. As células ectomesenquimais do folículo dentário, que contata a dentina radicular, diferenciam-se em cementoblastos, secretando cemento na raiz ${ }^{(36,37)}$. Ao mesmo tempo, as células do lado externo do folículo dentário diferenciam em osteoblastos e formam o osso alveolar. As da região central diferenciam-se em fibroblastos e formam o ligamento periodontal. As extremidades das fibras deste ligamento são chamadas de fibras de Sharpey. No processo de mineralização, elas ficam inseridas no cemento e no osso. O ligamento periodontal exerce a função de sustentação do dente, amortecendo o impacto das forças mastigatórias ${ }^{(36,37)}$.

O primeiro dente irrompe por volta do $6^{\circ}$ mês de idade e a raiz continua sua formação após esta fase. 
Quadro 1 - Marcos do Desenvolvimento Dental

\begin{tabular}{|c|c|c|}
\hline $\begin{array}{l}\text { Semana } \\
\text { vida intra } \\
\text { uterina }\end{array}$ & $\begin{array}{l}\text { Fases de } \\
\text { Desenvolvimento }\end{array}$ & Características \\
\hline $5^{a}$ & $\begin{array}{l}\text { Migração das } \\
\text { células da crista } \\
\text { neural }\end{array}$ & $\begin{array}{l}\text { Formação da lâmina vestibular e lâmina dentária, } \\
\text { onde ocorre a formação dentária. }\end{array}$ \\
\hline $7^{a}$ & Fase de Botão & $\begin{array}{l}\text { Saliências esféricas originadas da lâmina dentária que } \\
\text { se proliferam para dentro do ectomesênquima. }\end{array}$ \\
\hline $8^{a}$ & Fase de Capuz & $\begin{array}{l}\text { Diferenciação celular em epitélio interno, epitélio } \\
\text { externo e reticulo estrelado que dará origem ao órgão } \\
\text { do esmalte. } \\
\text { Diferenciação celular em papila dentária responsável } \\
\text { pela formação da dentina e polpa. O órgão do esmalte } \\
\text { mais a papila forma o germe dentário. }\end{array}$ \\
\hline $10^{a}$ & $\begin{array}{l}\text { Fase de } \\
\text { Campânula ou } \\
\text { Sino }\end{array}$ & $\begin{array}{l}\text { Determinação da forma do dente. Formação do } \\
\text { estrato intermediário que participa da formação do } \\
\text { esmalte. } \\
\text { Diferenciação de odontoblasto e ameloblasto. }\end{array}$ \\
\hline $12^{\mathrm{a}}$ & Fase da Coroa & $\begin{array}{l}\text { Deposição de dentina e esmalte inicia-se da cúspide } \\
\text { ou borda incisal e progride em direção a futura raiz. }\end{array}$ \\
\hline $28^{a}$ & Fase da Raiz & $\begin{array}{l}\text { Inicia-se quando a deposição de dentina e esmalte } \\
\text { atinge a alça cervical. Os odontoblastos passam a } \\
\text { formar dentina radicular e o folículo dentário nesta } \\
\text { fase forma o cemento, o ligamento periodontal e o } \\
\text { osso alveolar. }\end{array}$ \\
\hline
\end{tabular}

Referências: Katchburian \& Arana, 1999; Moore, Keith L., T.V.N. Persaud, 2014;

Nanci, 2013 


\section{JUSTIFICATIVA}

Os recursos digitais interativos evoluíram muito com surgimento da internet. Compreender o processo odontogênese é considerado um grande desfio para os alunos. Para minimizar essa dificuldade ou essa lacuna, faz-se necessária a utilização de novas ferramentas educacionais.

Neste contexto, construir um objeto de aprendizagem acerca da odontogênese, utilizando a computação gráfica que não se limita a produzir um desenho estático, mas abarca uma somatória de conhecimentos apresentados de forma dinâmica, pode em muito contribuir não só para a formação de estudantes de odontologia no Brasil, como se estender para a educação permanente de profissionais da saúde.

Esse estudo, além da construção do objeto de aprendizagem, se propõe a validá-lo junto aos professores com expertise nessa área. A validação de um objeto de aprendizagem é importante para que se identifiquem, em cada etapa da sua construção, possíveis inconsistências e reformulações. A avaliação de material didático digital é uma tarefa complexa e deve ser efetuada tanto na fase de desenvolvimento quanto na fase de utilização do software educativo, para que, posteriormente, ele seja oferecido aos professores e aos alunos. 


\section{OBJETIVO GERAL}

Construir e validar um objeto de aprendizagem sobre Odontogênese, direcionado a estudantes e profissionais da área da saúde.

\subsection{OBJETIVOS ESPECÍFICOS}

1. Construir um objeto de aprendizagem sobre a odontogênese, utilizando computação gráfica 3D.

2. Construir um processo de validação que inclui: elaboração de um instrumento de coleta específico, com diferentes domínios de análise; definição de respondentes; distribuição do material e análise de dados.

3. Validar esse objeto de aprendizagem por meio da análise crítica e sistematizada realizada por um conjunto de professores e profissionais de expertise reconhecida. 


\section{MÉTODOS}

O presente estudo foi aprovado no Comitê de Ética em Pesquisa da Faculdade de Medicina da Universidade de São Paulo, com protocolo de pesquisa $n$ ㅇ 446/13 (Anexo A). Sendo um estudo experimental, utilizou-se os recursos já existentes do Projeto Homem Virtual viabilizado pelo Projeto ProEnsino, Edital 24 do CAPES/MEC - SGTES/ MS.

Voltado para os alunos de graduação, nesse estudo buscou-se a construção inédita do objeto de aprendizagem utilizando tecnologia de ponta sobre o tema odontogênese. Tema esse complexo em vários ângulos, como a sua iniciação que se processa nas primeiras semanas de vida intrauterina, como sua visualização espacial retratada graças a utilização de ferramentas tecnológicas de modelagem gráficas 3D e extensa nomenclatura de estruturas que se morfo e histodiferenciam à medida que se processa seu desenvolvimento.

Este estudo foi dividido em três fases, a saber:

1. Construção do objeto de aprendizagem sobre odontogênese.

2. Validação do objeto de aprendizagem pelos professores.

3. Análise dos dados 


\subsection{Construção do objeto de aprendizagem sobre odontogênese.}

Os objetos de aprendizagem constituem um novo tipo de instrução que se configura como construções virtuais, programadas, que permitem designs, cores, movimentos e efeitos tridimensionais, utilizando linguagens de computação ${ }^{(39)}$. Essa versatilidade se confere pela possibilidade de agrupar imagens, textos, áudios, vídeos, a fim de enriquecer o material didático e interativo, formando assim uma unidade de conhecimento (40).

Entende-se por unidade de conhecimento um conjunto de objetos de aprendizagem interligados e apresentados por meio de ferramentas tecnológicas para fomentar um novo conhecimento. A unidade de conhecimento em um ambiente interativo de aprendizado democratiza o conhecimento, uma vez que, por meio dos recursos gráficos, facilita a compreensão das informações. Representa, portanto, efetiva modernização iconográfica educacional, que pode ser utilizada nos mais diversos propósitos ${ }^{(13)}$.

Essa unidade de conhecimento foi desenvolvida na disciplina de Telemedicina da Faculdade de Medicina da USP, chefiada pelo Prof. Dr. Chao Lung Wen.

$\mathrm{Na}$ disciplina de Telemedicina, há o Projeto Homem Virtual, que representa um novo método de comunicação dinâmica e dirigida. Utiliza a representação gráfica que contém uma gama de informações especializadas, de forma interativa, dinâmica e objetiva. Utilizando tecnologia de modelagem gráfica em 3D, o Projeto Homem Virtual é uma forma eficiente de transmitir conhecimentos de anatomia, fisiologia, fisiopatologia e mecanismos moleculares. Representa uma efetiva modernização nas iconográficas educacionais, uma vez que facilita e agiliza o entendimento em relação a um assunto específico ${ }^{(13)}$.

Por meio deste objeto de aprendizagem assiste-se a imagens de estruturas anatômicas em 3D com movimentos fisiológicos, observa-se à 
biomecânica e à dinâmica funcional que seriam impossíveis de serem demonstradas por métodos convencionais ${ }^{(1)}$.

Essas imagens são usadas para apoiar o estudo dos alunos e a capacitação de profissionais em qualquer local de ensino superior odontológico. Pode ser utilizada em todos os níveis educacionais. O desenvolvimento deste objeto de aprendizagem requer a aliança de conhecimentos na área de odontologia, tecnologia da informação, telemedicina e teleducação interativa ${ }^{(15)}$.

O projeto e construção de objetos de aprendizagem demandam um complexo arranjo de habilidades multidisciplinares. Esse processo deve ser cuidadosamente planejado e metodicamente desenvolvido, pois para produzir um objeto de aprendizagem, destacamos a necessidade de conhecer a temática que se deseja trabalhar; determinar a abordagem pedagógica que norteará sua concepção e uso; saber utilizar ferramentas de autoria para sua construção e trabalhar de forma coerente com os princípios do projeto educacional (21).

Para a construção desse objeto de aprendizagem em modelação gráfica, foi feita ampla revisão da literatura e foi firmada a parceria com o Prof. Dr. Victor Arana, professor renomado e titular da Disciplina de Embriologia Oral da Faculdade de Odontologia da USP, que norteou a elaboração de um roteiro para confecção gráfica sobre odontogênese. Cada etapa do processo de criação foi acompanhada pela pesquisadora e validada por três especialistas nesta área do conhecimento.

A construção e desenvolvimento das sequências do material interativo foi dividido em fases:

\section{Primeira fase:}

Para identificação e organização dos marcos científicos mais relevantes; sua sequência e cronologia correta associada com a revisão da literatura das etapas da odontogênese, utilizou-se uma matriz de objetivos e competências.

Essa matriz é formada por três eixos: 
a) importância temática relativa, isto é, ponderação da importância do assunto quando comparado uns aos outros - avaliação vertical (1 a 5) - V;

(b) importância do tema para os estudantes (1 a 5) - O e;

(c) avaliação horizontal para a ponderação da importância do tema para fins de aplicação prática (1 a 5) - PR

A seleção foi feita a partir da pontuação final obtida por meio da multiplicação dos valores dos 3 eixos.

Quadro 2 - Matriz de objetivos e competências

\begin{tabular}{|c|c|c|c|c|c|c|}
\hline \multirow{2}{*}{ Assunto } & \multirow{2}{*}{$\begin{array}{l}\text { Objetivo: } \\
\text { construção }\end{array}$} & \multirow{2}{*}{ Competência: conhecer } & \multicolumn{3}{|c|}{ Pontuação } & \multirow{2}{*}{$\frac{\text { VxOxPR }}{\text { Total }}$} \\
\hline & & & V & 0 & PR & \\
\hline $\begin{array}{l}\text { Estruturas } \\
\text { anatômicas - } \\
\text { face }\end{array}$ & $\begin{array}{l}\text { Formação da } \\
\text { face }\end{array}$ & $\begin{array}{l}\text { Formação da lâmina vestibular } \\
\text { e lâmina dentária, onde ocorre } \\
\text { a formação dentária. }\end{array}$ & 3 & 3 & 4 & 36 \\
\hline $\begin{array}{l}\text { Fase de } \\
\text { botão }\end{array}$ & $\begin{array}{l}\text { Mostrar a } \\
\text { proliferação } \\
\text { celular. }\end{array}$ & $\begin{array}{l}\text { Saliências esféricas que se } \\
\text { proliferam para dentro do } \\
\text { ectomesênquima. }\end{array}$ & 3 & 3 & 4 & 36 \\
\hline $\begin{array}{l}\text { Fase de } \\
\text { capuz }\end{array}$ & $\begin{array}{l}\text { Mostrar a } \\
\text { histodiferenciaç } \\
\text { ão }\end{array}$ & $\begin{array}{l}\text { Epitélio interno, epitélio } \\
\text { externo e reticulo estrelado, } \\
\text { papila dentária, germe } \\
\text { dentário. }\end{array}$ & 4 & 4 & 3 & 48 \\
\hline $\begin{array}{l}\text { Fase de } \\
\text { campânula }\end{array}$ & $\begin{array}{l}\text { Diferenciação } \\
\text { celular e } \\
\text { morfológica }\end{array}$ & $\begin{array}{l}\text { Determinação da forma do } \\
\text { dente. Estrato intermediário, } \\
\text { odontoblasto e ameloblasto. }\end{array}$ & 5 & 5 & 4 & 100 \\
\hline $\begin{array}{l}\text { Fase da } \\
\text { coroa }\end{array}$ & $\begin{array}{l}\text { Deposição de } \\
\text { dentina e } \\
\text { esmalte }\end{array}$ & $\begin{array}{l}\text { Deposição de dentina e } \\
\text { esmalte inicia-se da cúspide } \\
\text { ou borda incisal e progride em } \\
\text { direção a futura raiz. }\end{array}$ & 5 & 5 & 5 & 125 \\
\hline Fase da raiz & $\begin{array}{l}\text { Formação } \\
\text { radicular }\end{array}$ & $\begin{array}{l}\text { Odontoblastos secreta dentina } \\
\text { radicular e o folículo dentário } \\
\text { nesta fase secreta cemento. } \\
\text { Ligamento periodontal e o } \\
\text { osso alveolar. }\end{array}$ & 5 & 3 & 5 & 75 \\
\hline
\end{tabular}

Fonte: Desenvolvido pela Disciplina de Telemedicina da Faculdade de Medicina da USP 


\section{Segunda fase:}

Sequência e ordem cronológica dos acontecimentos desses marcos relevantes para a construção de um roteiro científico com a sequência evolutiva desses acontecimentos.

\section{Terceira fase:}

Processo dinâmico desses marcos relevantes encadeado para a execução da modelagem e experimentação, reunindo todos os materiais existentes, histológicos, fotográficos, que puderam subsidiar o roteiro científico.

\section{Quarta fase:}

Construção das estruturas da odontogênese a partir dos recursos computacionais gráficos tridimensionais. A produção deste objeto de aprendizagem é dividida em: modelagem, animação, texturização, iluminação, renderização, composição e pós-produção. 
- Modelagem: Com base em referências fornecidas pela literatura e por especialistas, parte-se para a modelagem estrutural de um objeto ou estrutura. O modelo 3D é conseguido por meio da manipulação de polígonos de um objeto primitivo simples, que é subdividido e modificado até alcançar a forma desejada. Os programas utilizados para essa finalidade são o 3DS Max e o ZBrush (Figura1).

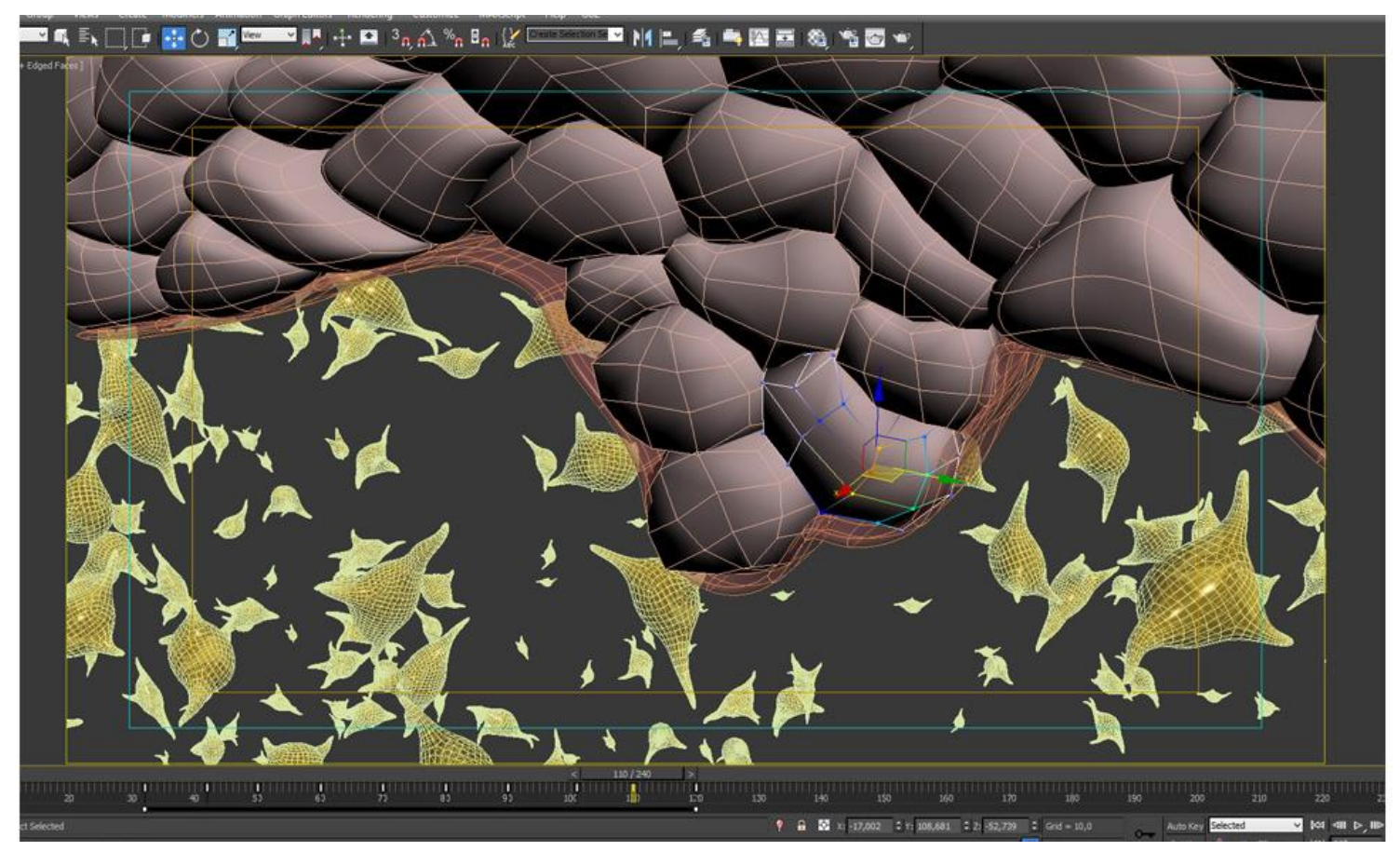

Figura 1 - Passo 1: Modelagem - processo de modelagem poligonal em software 3D.

- Animação: Seguindo um roteiro pré-estabelecido, as estruturas modeladas são unidas em diversas pequenas sequências dinâmicas. A fim de oferecer maior movimentação e melhor visualização dessas sequências, foram utilizados recursos cinematográficos de movimentação de câmera, trabalhando as estruturas tridimensionais em seus melhores ângulos, com aproximação e afastamento de câmera, com o intuito de oferecer visões micro e macro do processo de odontogênese (Figura 2).

É importante destacar que o resultado desta fase são várias sequências de animações que, posteriormente, serão unidas umas às outras na fase de composição e pós-produção, descrita mais adiante. 


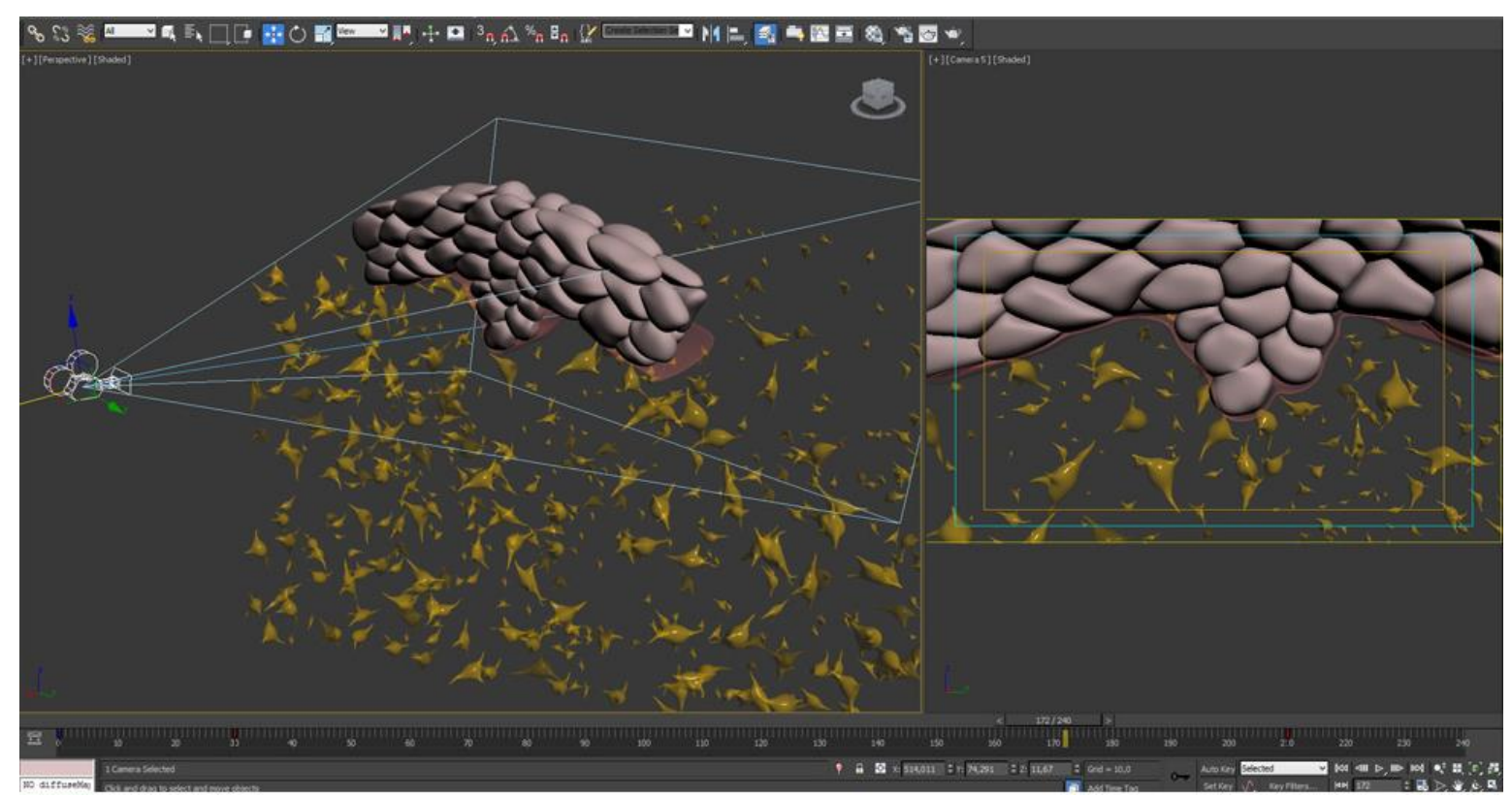

Figura 2 - Passo 2: Animação - processo de animar uma câmera ou objeto.

- Texturização: É a aplicação de pintura ao modelo previamente construído com uso de brushes (pincéis) especiais e/ou revestimento do objeto tridimensional com malha de texturas, cores, nuances e padrões. Isso diferencia as diversas texturas ou revestimentos do modelo 3D, como por exemplo, os de tecidos do corpo humano. A texturização aprimora o modelo e o aproxima das suas características reais. São usados o ZBrush e o Photoshop para criar as texturas e o 3DS Max para demais efeitos, como refrações, reflexos, pequenas ranhuras com base em padrões, entre outros (Figura 3). 


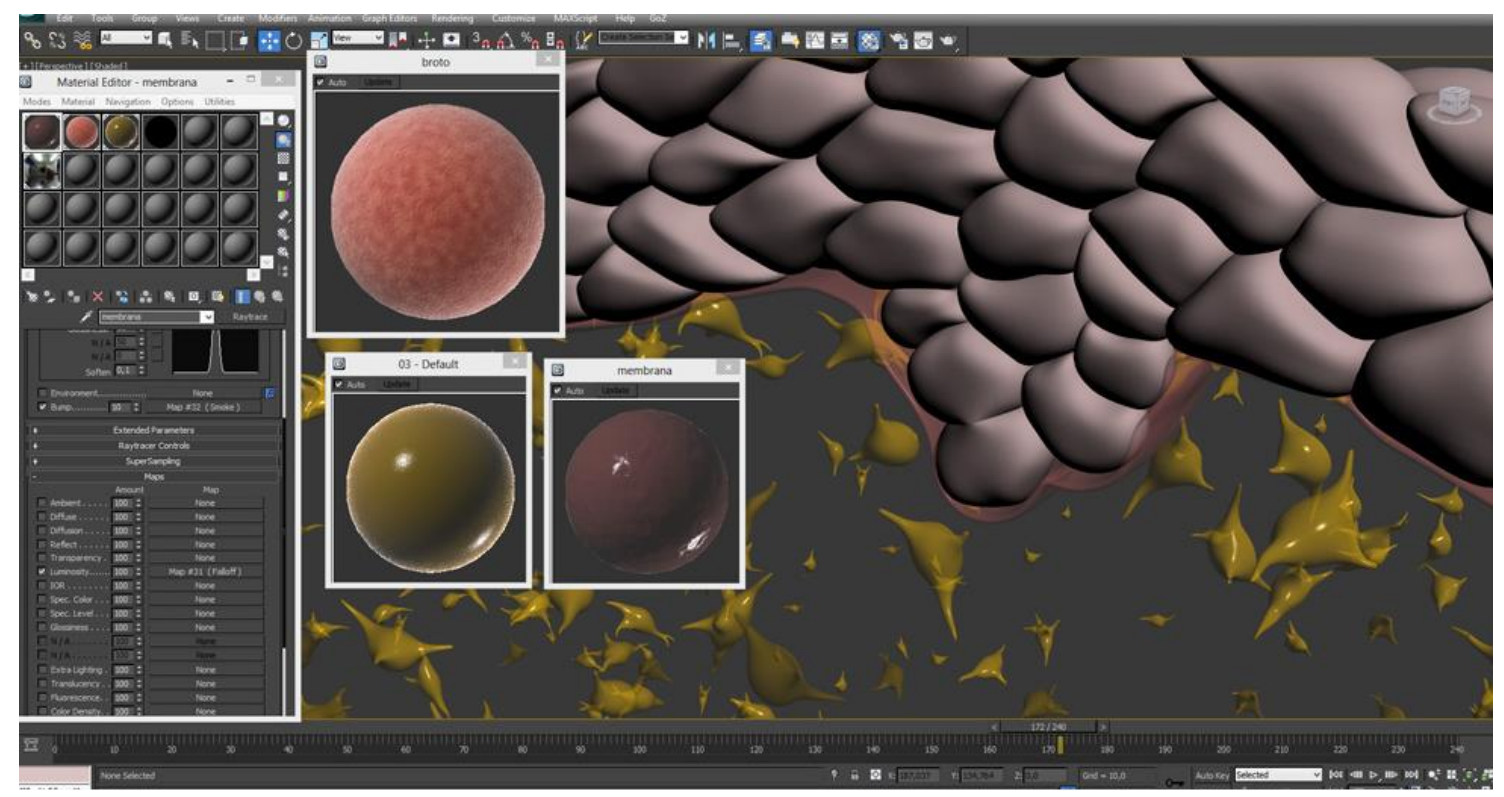

Figura 3 - Passo 3: Texturização - processo de aplicação de material com informação de cor, textura, rugosidade e brilho.

- lluminação e Renderização: Para dar beleza e destaque às cenas, é necessário aplicar luzes e configurar o módulo de renderização, que irá gerar o filme, compilando todas as informações de cor, textura, movimento, luz e sombra e forma, em uma sequência de imagens. A renderização é feita no programa 3DS Max que possibilita o uso de uma série de tipos de luzes, cada qual com suas características de projeção e com várias configurações para determinar cor, tipo de sombra, especular e intensidade. 


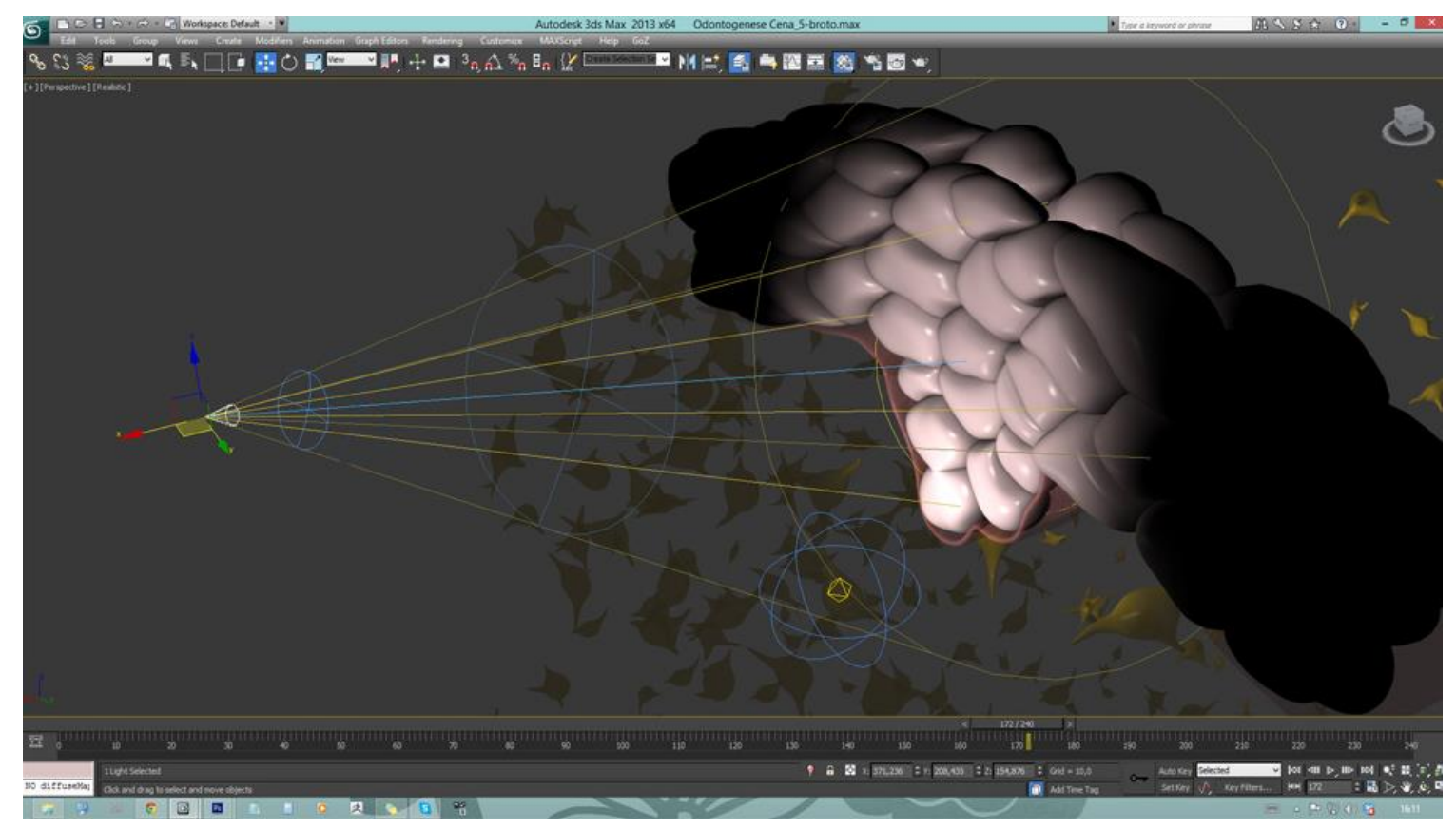

Figura 4 - Passo 4: lluminação - processo de aplicar diferentes tipos de luzes para iluminar a cena.

- Composição e pós-produção: A sequência de imagens e de animações obtida no programa 3D é definida por um roteiro de pós-produção baseado na utilização que será feita do modelo. Este roteiro é construído pelos especialistas em conjuntos com os designers, contemplando, além da sequência de imagens, a inserção de efeitos especiais, cortes, transição, máscaras, tratamento de cores, legendas e sons. O programa utilizado nesta fase é o Adobe AfterEffects (Figura 5). 


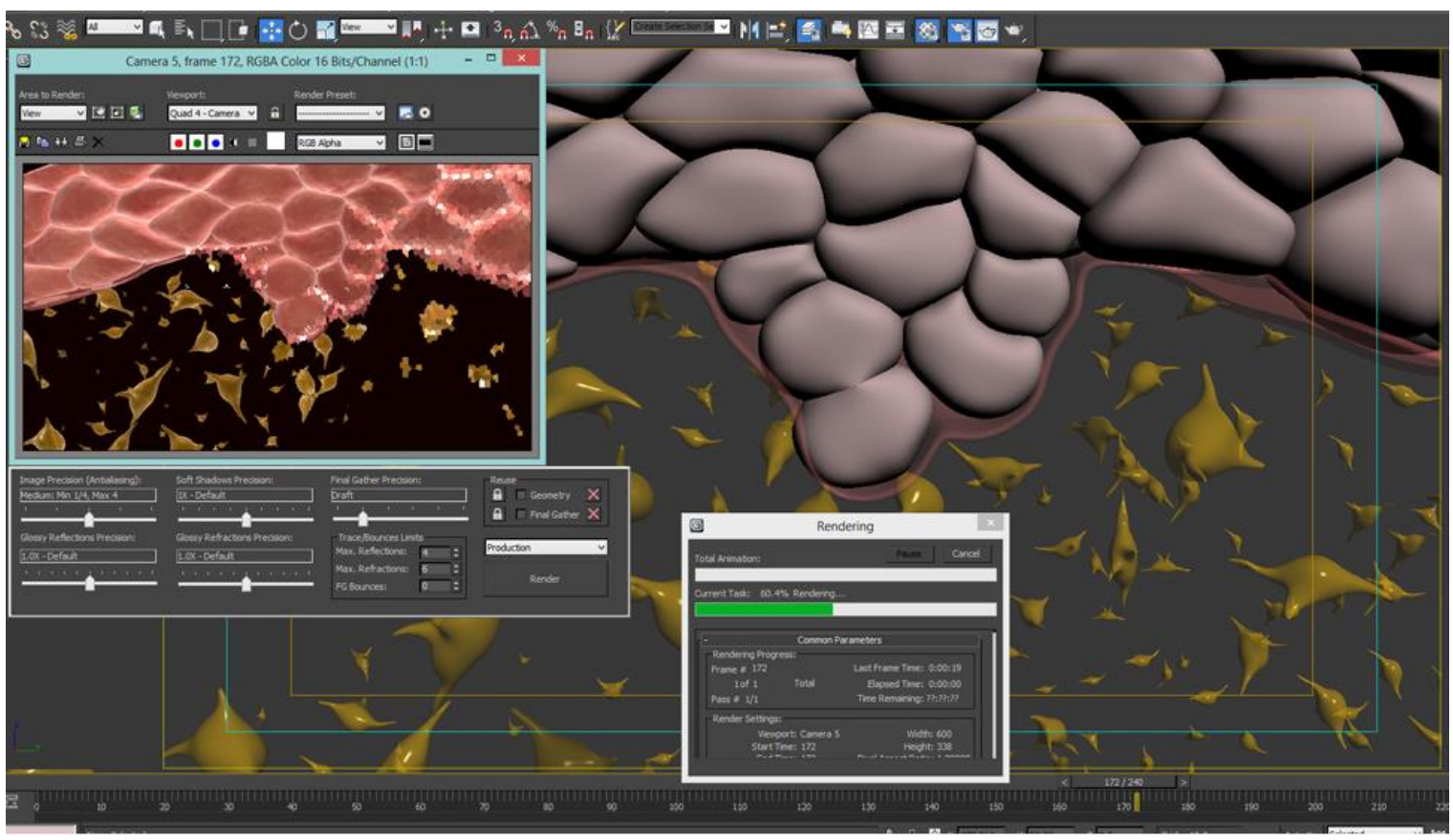

Figura 5 - Passo 5: Renderização - processo de render transforma a cena criada e animada em vários frames ou fotos.

Ainda nesta fase, foram adicionadas legendas e coloração para destacar as diversas estruturas celulares que vão diferenciando ao longo do processo de formação dental. Por exemplo, no canto esquerdo superior do processo de formação dental, está sinalizado a fase construída e no canto superior direito são identificadas a idade cronologia da formação dentaria, são elas: $6^{\underline{a}}, 8^{\underline{a}}, 11^{\underline{a}}, 12^{\underline{a}}$ e $18^{\mathrm{a}}$ semanas. Além disso, foi feito um roteiro de locução e legenda da narrativa de todo o processo da odontogênese.

A produção do objeto de aprendizagem de cada fase da odontogênese seguiu o método descrito acima. E para cada construção de trechos do processo, foram feitas reuniões para acertos e avaliações do material. Uma vez avaliado, dava-se prosseguimento para a fase seguinte.

O produto final é um objeto de aprendizagem de 9 minutos contendo uma narrativa que destaca as informações mais significativas de cada fase do processo da odontogênese. 


\subsection{Validação do objeto de aprendizagem sobre a odontogênese.}

A validação é a etapa final da construção de um objeto de aprendizagem.

Esse estudo foi realizado a partir da análise crítica e sistematizada do material produzido por professores e/ou especialistas de expertise reconhecida na área da histologia, embriologia humana e formação da face, com pelo menos 10 anos de atuação na área.

Baseada em extensa revisão de literatura e consenso de especialistas em educação na área de saúde, que revisaram o material para a finalidade de validação, construiu-se um instrumento de coleta de dados quantitativos com base no modelo de escala Likert. Esse instrumento é auto responsivo com cinco possibilidades de resposta a saber: concordo totalmente (CT), concordo (C), indiferente (I), discordo (D) e discordo totalmente (DT). Ele contém 39 afirmações com respostas com os seguintes escores para cada uma das respostas: $5=C T$, $4=\mathrm{C}, 3=\mathrm{I}, 2=\mathrm{D}, 1=\mathrm{DT} ; 9$ questões em que o participante dará nota de zero a dez e 3 questões abertas abordando as forças, fraquezas e sugestões para validação do constructo (Anexo II).

Os professores foram convidados por meio de uma carta convite via email e apresentados à plataforma educacional Nuvem do Conhecimento. Essa plataforma educacional é um ambiente interativo de aprendizagem desenvolvida pela Disciplina de Telemedicina da Faculdade de Medicina da USP e chefiada pelo Prof. Chao Lung Wen.

O ambiente interativo de aprendizagem foi desenvolvido de maneira a garantir a confidencialidade e o anonimato das respostas dos participantes. Os participantes tiveram 20 dias disponíveis de acesso para validar o material.

Para acesso ao material do estudo criou-se um link para os professores validadores se cadastrarem na plataforma:

http://nuvemdoconhecimento.org.br/aia/controle/inscricao/inscricao.php? $c=T E L E-V L P O$ 
Após o cadastro, os professores seguiram o tutorial abaixo:

- Acessar o site http://nuvemdoconhecimento.org.br/aia/

- Clicar no botão Odontogênese

- Informar os dados de autenticação (e-mail e senha)

- Caso não tenha alterado a senha, a senha inicial é telemedicina

- Preencher o termo de consentimento para liberar o acesso aos conteúdos.

Os validadores se cadastram, acessam a plataforma e aceitam o termo de consentimento (Anexo I) ao material produzido e questionário de validação. 

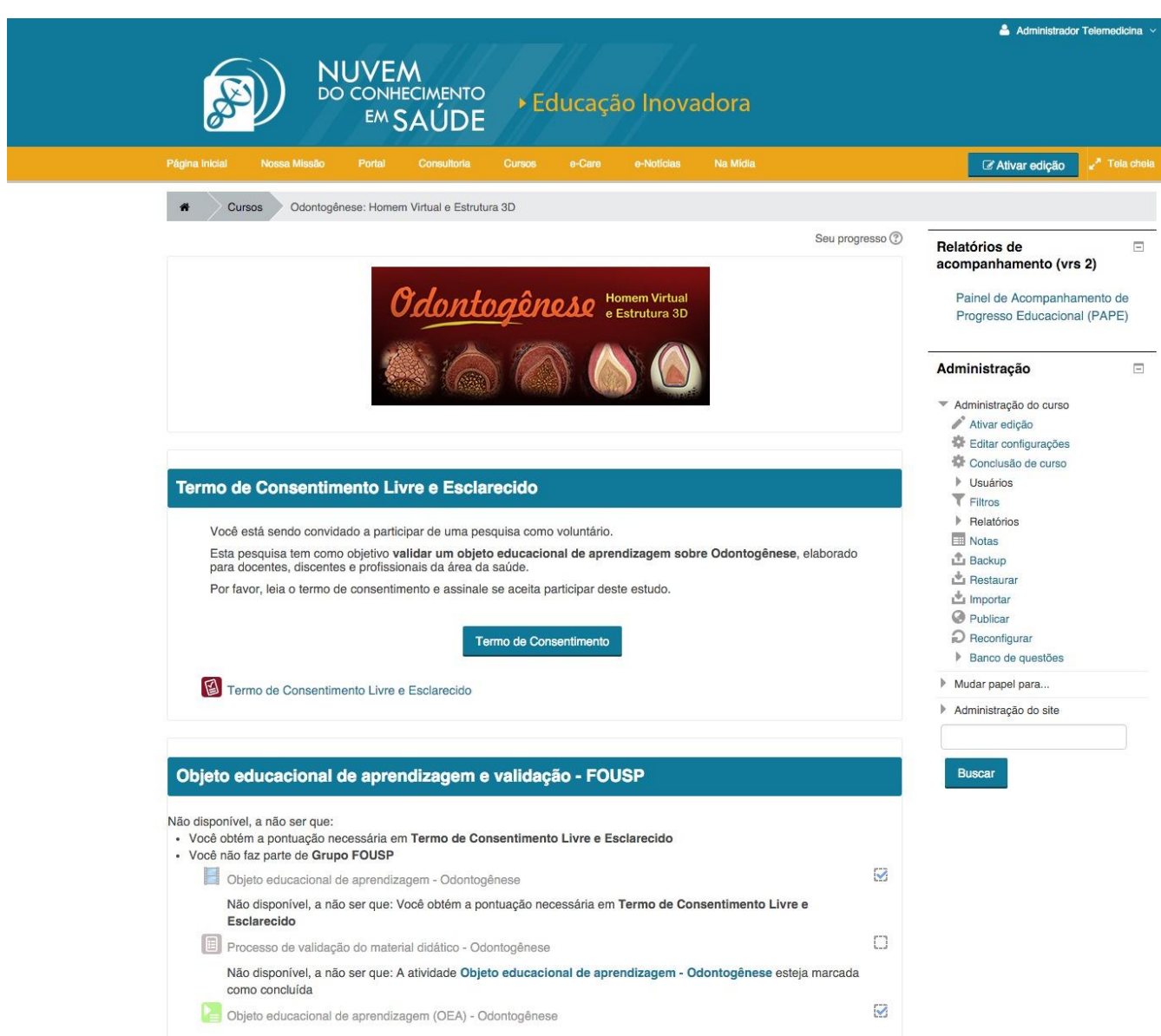

acompanhamento (vrs 2)

Painel de Acompanhamento de
Progresso Educacional (PAPE)

Administração

$\checkmark$ Administraçăo do curso

Ativar ediçăo

* Editar conitiguraçōes

Usuários

$\checkmark$ Filtros

1 Relatórios

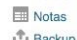

山 Beckup

山 Importar

Publicar

Deconifurar
, Barco de questos

- Mudar papel para...

1) Administração do siț

Buscar

\section{Objeto educacional de aprendizagem e validação}

Nāo disponivel, a nāo ser que:

- Você obtém a pontuaçăo necessária em Termo de Consentimento Livre e Esclarecido

Ocê faz parte de Grupo FOUSP escondido caso contrário

国 Video: Odontogênese

[i] Questionário sobre a Odontogênese

Năo disponivel, a năo ser que: A atividade Video: Odontogênese esteja marcada como concluida

圆 Processo de validaçăo do material didático - Odontogênese

Naao disponivel, a năo ser que: A atividade Video: Odontogênese esteja marcada como concluida

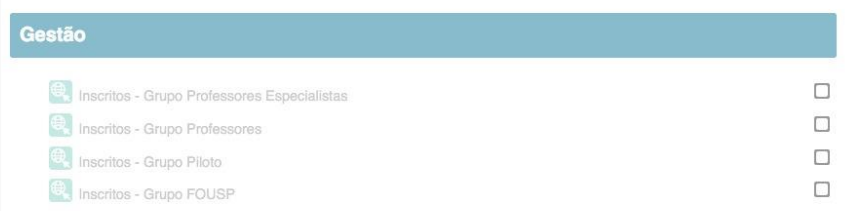

Figura 6 - Plataforma interativa de aprendizagem Nuvem do Conhecimento. 


\subsection{Análise dos dados}

Os professores e profissionais com expertise reconhecida validaram o objeto de aprendizagem por meio do instrumento específico pela autora. Os dados relativos às suas percepções foram analisados utilizando o software para análise estatística de dados, Statistical Package for Social Science for Windows (SPSS).

Os dados foram submetidos à análise de confiabilidade do coeficiente alfa de Cronbach, no qual valores maiores ou iguais a 0,7 são considerados satisfatórios ${ }^{(41-43)}$.

Os resultados quantitativos obtidos no estudo foram expressos por frequência e percentuais.

$\mathrm{Na}$ análise de item do instrumento, inicialmente, foram construídos histogramas de frequência das cinco diferentes possibilidades de resposta (CT, C, I, D, DT) para cada uma das 39 afirmações propostas. Em seguida, foi feito um agrupamento das respostas $C T$ e $C$, para o qual foi atribuída uma visão positiva dos respondentes com relação à afirmação. As respostas I, D e DT, foram agrupadas da mesma forma e consideradas como visão negativa acerca da afirmativa.

Utilizaremos para análise de conteúdo, das forças e fraquezas contidas no instrumento de coleta, a técnica de Bardin ${ }^{(44)}$. Consideramos que a obra de Laurence Bardin possui uma ancoragem consistente no rigor metodológico, com uma organização propícia à compreensão aprofundada do método, ou seja, a organização da análise; a codificação de resultados; as categorizações; as inferências; e, por fim, a informatização da análise das comunicações. Ao mesmo tempo, traz aos pesquisadores um caminho multifacetado que caracteriza a Análise de Conteúdo como um método que, historicamente e cotidianamente, produz sentidos e significados na diversidade de amostragem presentes no mundo acadêmico ${ }^{(45)}$.

A análise dos dados qualitativos compreendeu as seguintes etapas: a) Preparação do material - digitação das respostas das questões abertas e 
organização dos dados; b) Pré-análise - realização de leitura flutuante; c) Categorização - destaque de assuntos por relevância e/ou por repetição, transformando dados brutos em organizados; d) Validação externa - discussão dos resultados entre pesquisadores independentes; e) Apresentação dos resultados - de forma descritiva e com citações ilustrativas das falas, preparando o resultado para discussão, inferência e interpretação ${ }^{(44,46-48)}$. 


\section{RESULTADOS}

\subsection{Objeto de Aprendizagem}

O objeto de aprendizagem sobre a odontogênese representa a densidade de uma síntese de informação, equivalente ao conhecimento de várias produções intelectuais compiladas $(35,37,38,49)$.

As imagens tridimensionais e dinâmicas facilitam a compreensão do processo dinâmico de formação do dente tornando mais claro o entendimento e aprendizado; além de trazer cenas não visualizáveis em um único plano de imagem, frequentemente presente nos livros textos.

Formatou-se essa produção intelectual em vídeo para facilitar a acessibilidade, comunicação e veiculação por meio das mídias e a internet, e principalmente, para possibilitar a difusão do conhecimento.

O vídeo tem duração de 9 minutos, com legendas indicando estruturas celulares, as fases da odontogênese e a cronologia dos acontecimentos juntamente com a narrativa.

Construiu-se um espaço para depósito deste vídeo em plataforma eletrônica de reconhecida qualidade e segurança no link http://nuvemdoconhecimento.org.br/aia/course/view.php?id=39 


\subsection{Processo de validação do objeto de aprendizagem}

Foram convidados 25 professores e profissionais que ministram aulas sobre o tema odontogênese para validação. Um não aceitou, dois aceitaram, mas não concluíram. As análises incluíram um total de 22 respondentes.

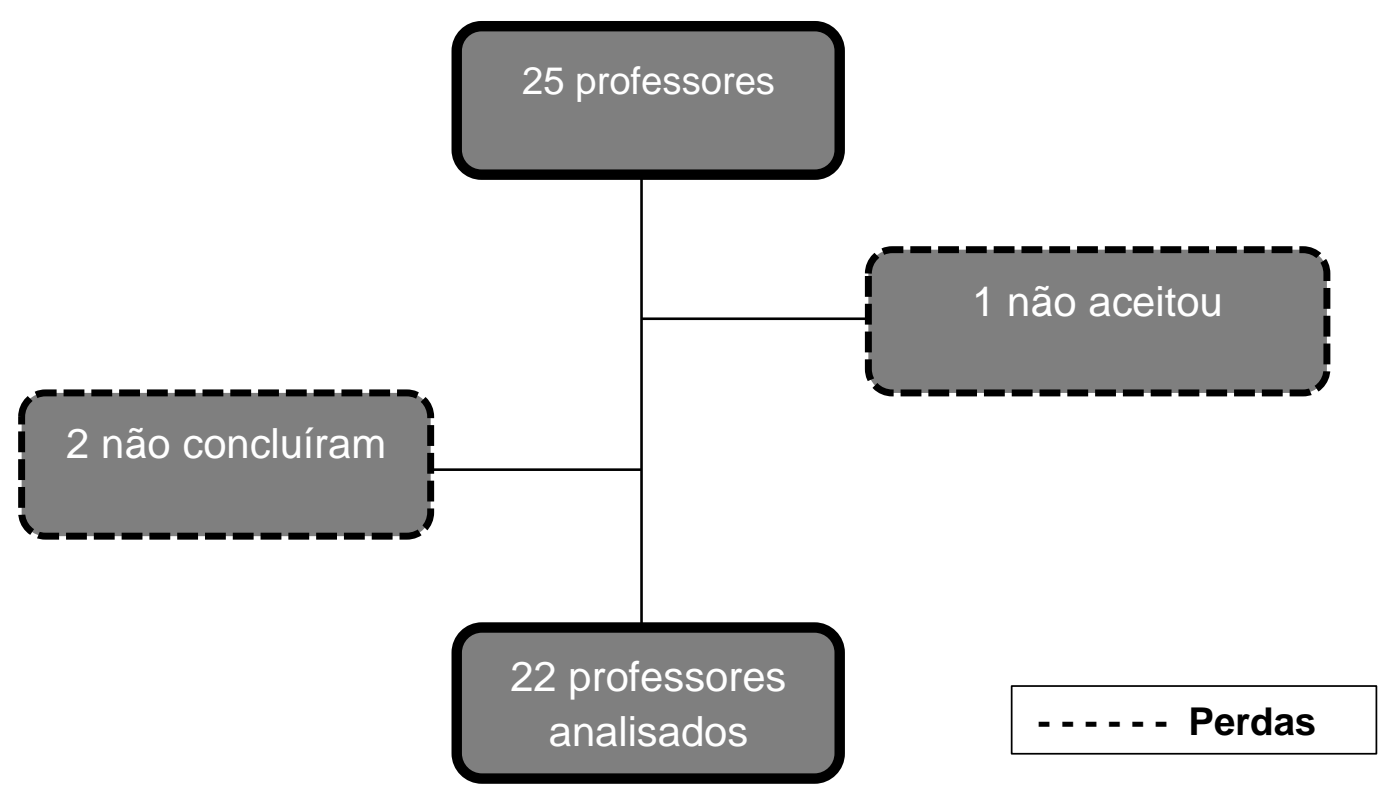

Figura 7 - Fluxograma de participantes e perdas do estudo.

\subsubsection{Amostra dos participantes}

Foram selecionados nove centros universitários de vários estados e cidades brasileiras. Entre os respondentes, 30\% são da Faculdade de Odontologia de Bauru (FOB), estado de São Paulo; 20\% da Faculdade de Odontologia da Universidade de São Paulo (FOUSP), na capital de São Paulo; 15\% da Universidade Estadual de Maringá (UEM), no estado do Paraná; $5 \%$ da Universidade Estadual de Araraquara (UNESP), estado de São Paulo; 5\% da Universidade Federal de Pernambuco (UFP), no estado de Pernambuco; 5\% 
Universidade Estadual de Lins (UNESP), estado de São Paulo; 5\% da Universidade Estadual do Amazonas (UEA), em Manaus, 10\% da Universidade Sagrado Coração (USC), cidade de Bauru em São Paulo; e 5\% da Universidade Paulista (UNIP), na capital São Paulo .

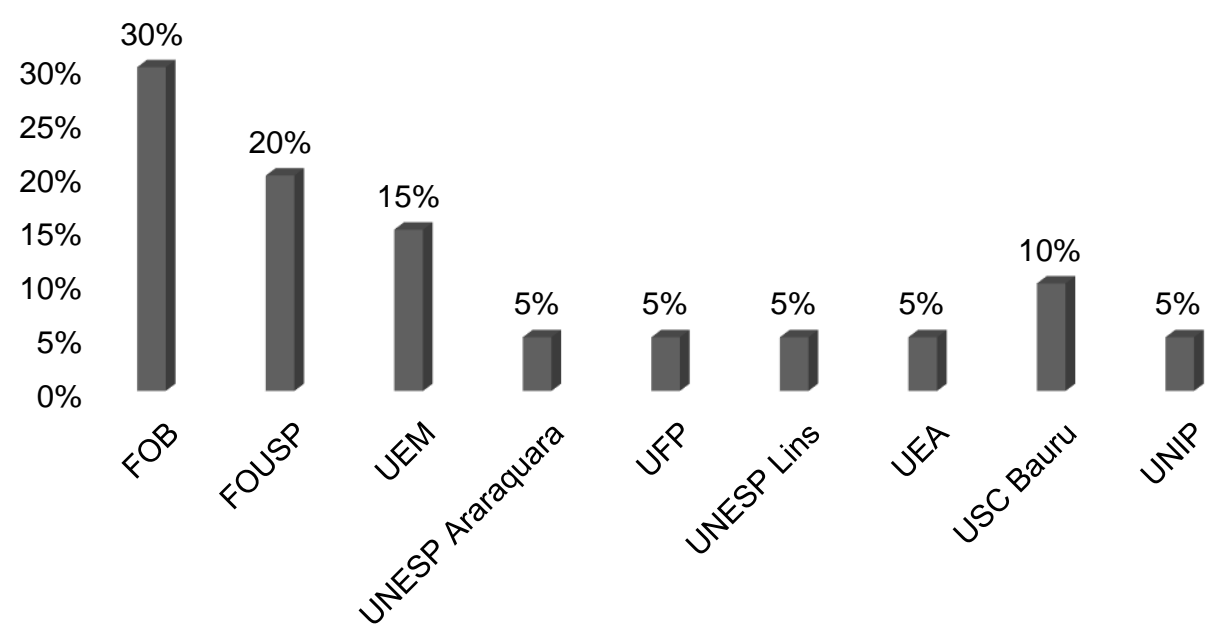

Figura 8 - Distribuição do grupo de validadores por instituição de ensino.

Quanto à titulação dos participantes nessa amostra de conveniência, dois têm o título de mestrado e 20 participantes possuem título de doutorado. Em relação ao tempo de experiência com educação em saúde, 8 docentes atuam na profissão de 12 a 20 anos e 14 docentes atuam há mais de 20 anos. 


\subsubsection{Análise dos dados quantitativo}

A análise dos dados apontou para uma distribuição desviada, nãoparamétrica. Considerando a escala Likert ordinal e o número reduzido da amostra, utilizamos estatística descritiva com apresentação da distribuição das respostas pela frequência em histograma e mediana com intervalo interquartil e percentil 25-75\% para visualização da distribuição das respostas ${ }^{(50)}$.

O valor obtido do coeficiente de alfa de Cronbach encontrado na análise de consistência interna do instrumento de coleta de dados quantitativos revelou um alfa $=0,850$ que confirma a consistência do instrumento de coleta utilizado na validação do objeto de aprendizagem.

A partir da análise dos dados quantitativos, foram construídos histográficos e tabelas que demonstram a percentagem de respostas de acordo com a opinião dos professores em cada uma das afirmações do instrumento de coleta de dados. 
1. O video permitiu o meu entendimento de todas as fases da odontogênese.

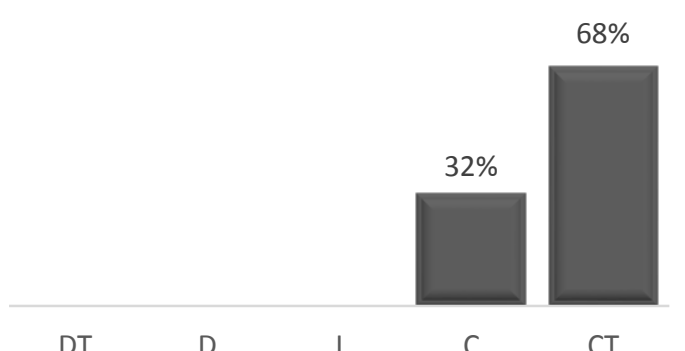

3. Os movimentos das cenas foram esclarecedores para mim
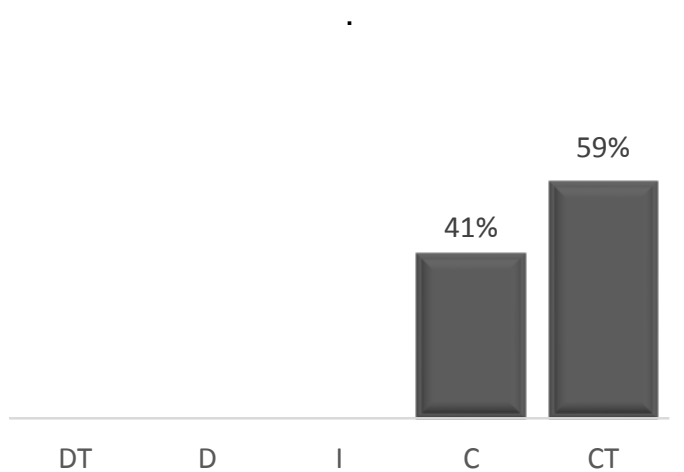

5. A iluminação do vídeo foi apropriada

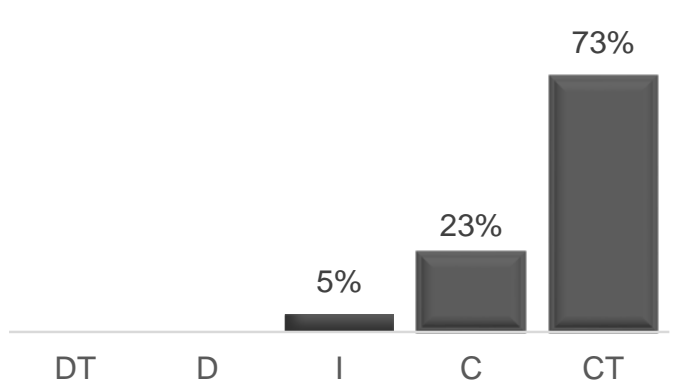

2. A narração mostrou-se necessária ao meu entendimento do tema.

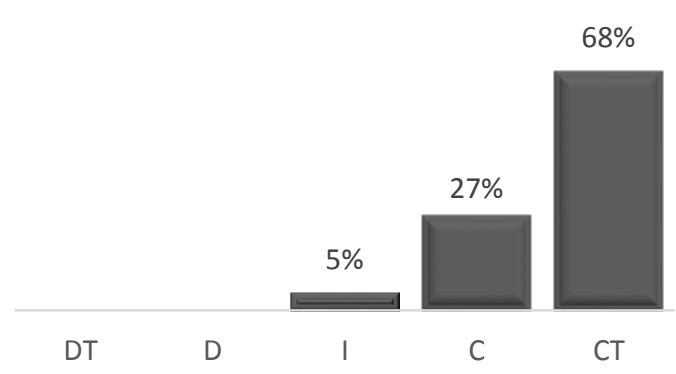

4. As cores apresentadas estão de acordo com a norma internacional

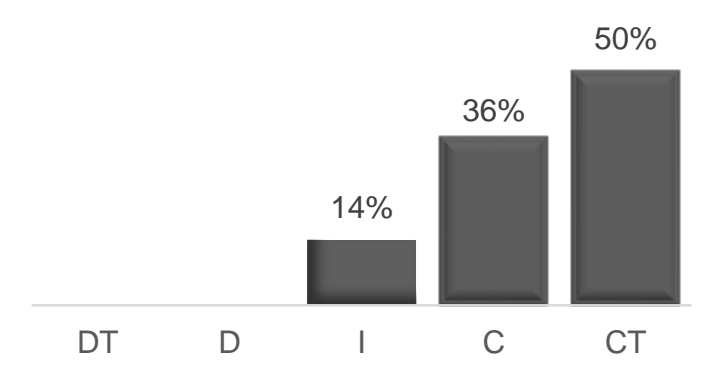

6.O uso de imagens tridimensionais auxiliou o meu entendimento do tema

Figura 9 - Análise de item das afirmativas 1 a 6 (CT, concordo totalmente; C, concordo; I, indiferente; D, discordo; DT, discordo totalmente). 
7. Considero a odontogênese uma temática batante simples

$68 \%$

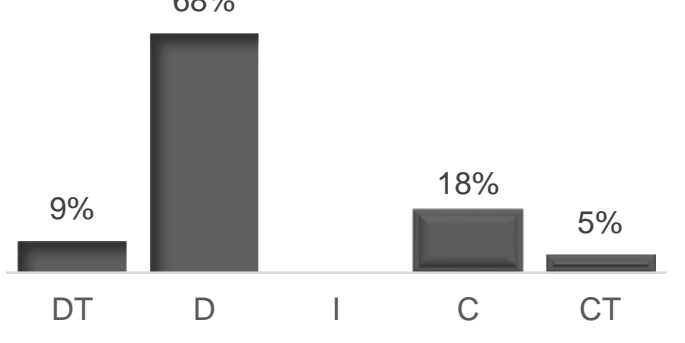

9. O formato de vídeo de animação facilitou o meu aprendizado

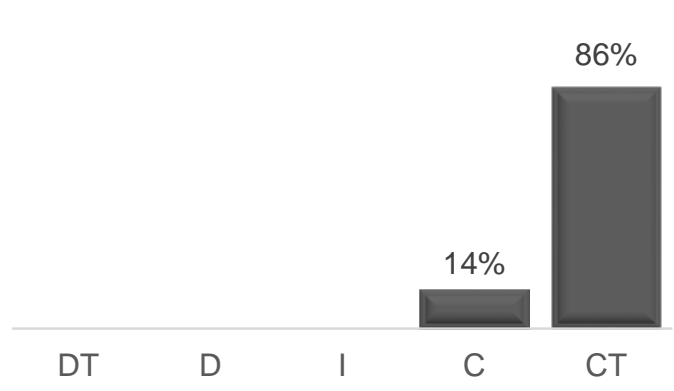

11. A visualização do vídeo foi possível no meu computador

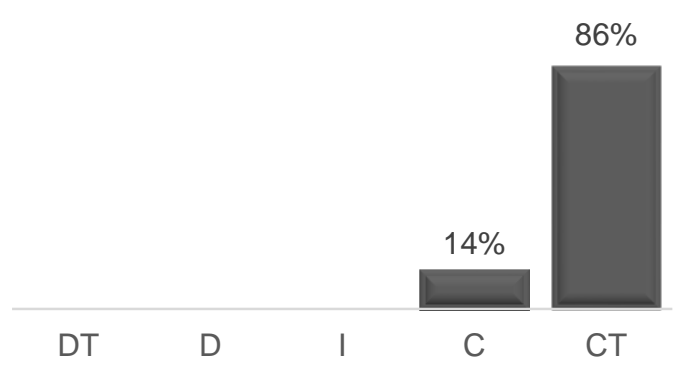

8. O conhecimento da odontogênese é fundamental para um odontólogo

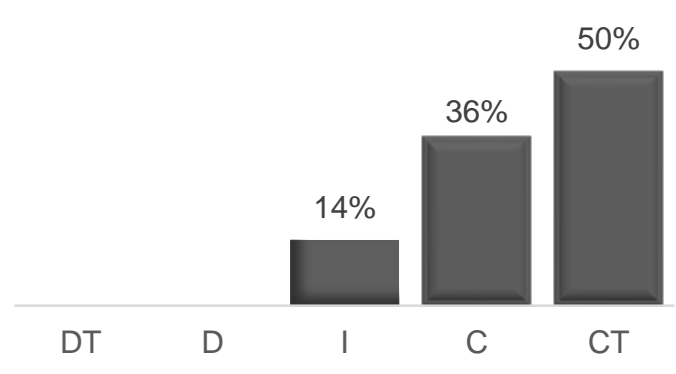

10. O conteúdo apresentado está atualizado

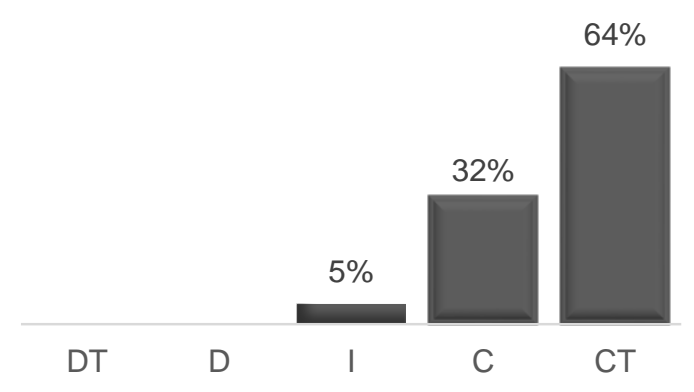

12. O meu acesso ao ambiente virtual de aprendizado foi fácil

Figura 10 - Análise de item das afirmativas 7 a 12 (CT, concordo totalmente; C, concordo; I, indiferente; D, discordo; DT, discordo totalmente). 
13. As legendas estão de acordo com as imagens

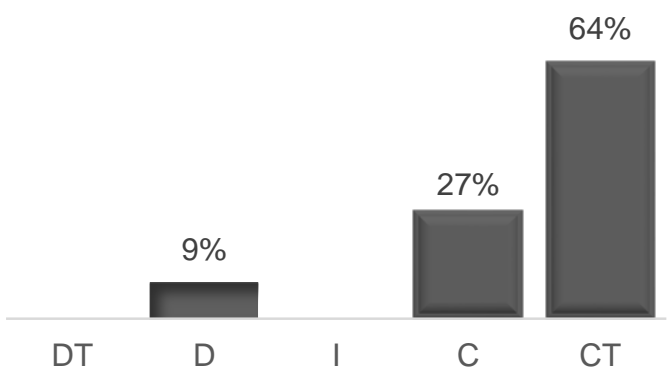

15. O tempo do vídeo é suficiente para um bom entendimento do assunto

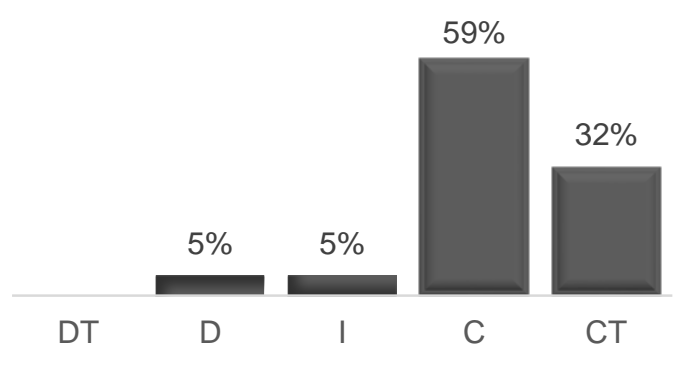

17. As imagens são norteadas pela teoria
14. As indicações nas imagens facilitaram a minha compreensão
16. O vídeo apresentou corretamente a sequência da odontogênese

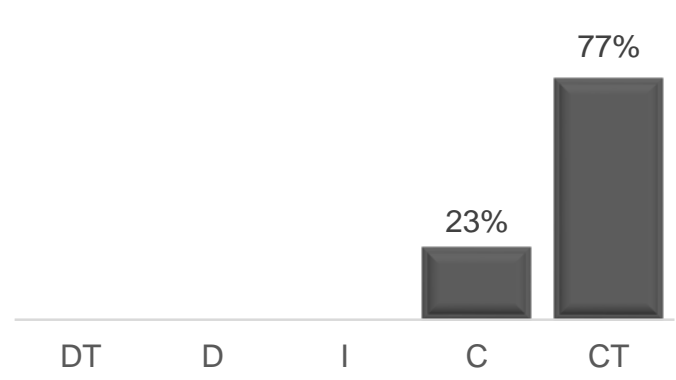

$82 \%$

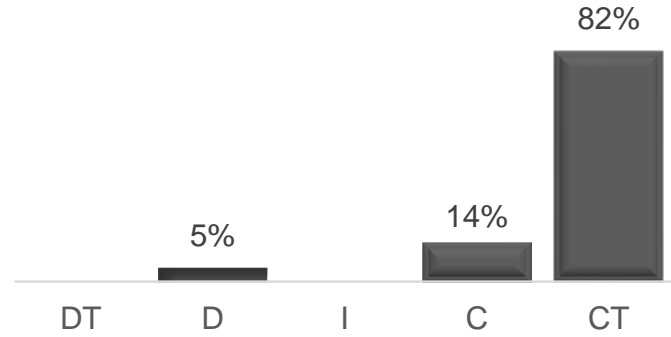

18. A linguagem utilizada permitiu minha compreensão sobre a odontogênese

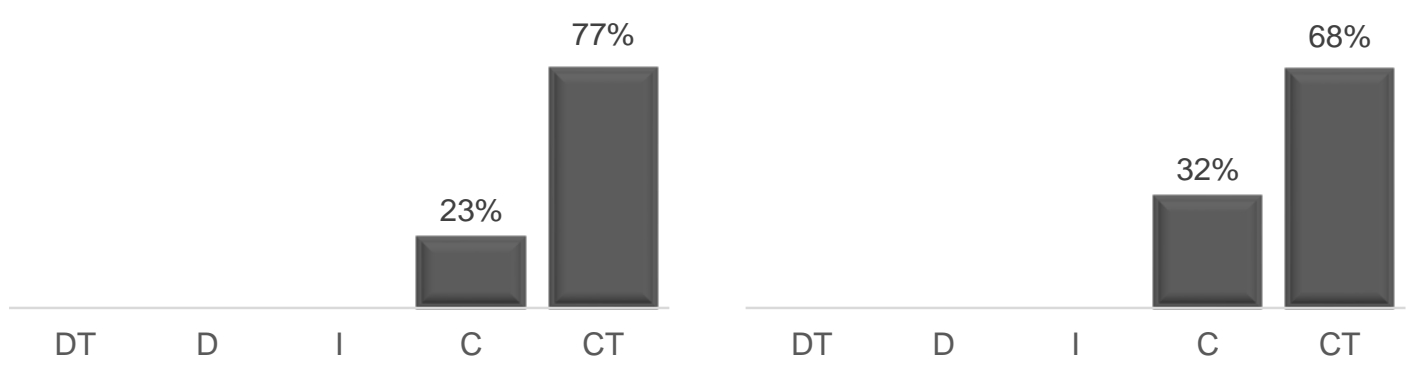

Figura 11 - Análise de item das afirmativas 13 a 18 (CT, concordo totalmente; C, concordo; I, indiferente; D, discordo; DT, discordo totalmente). 
19. A narração do vídeo foi agradável

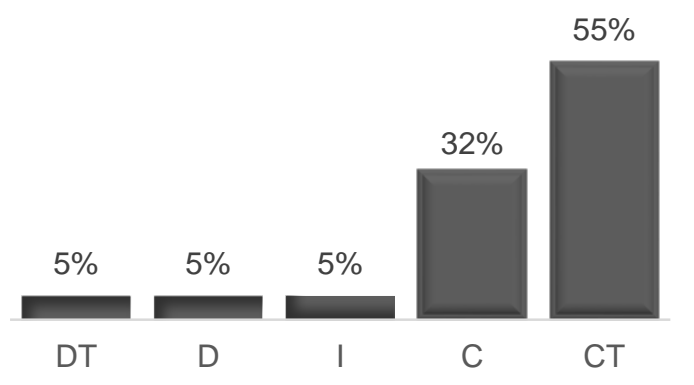

21. Considero que o vídeo pode facilitar o aprendizado sobre o tema

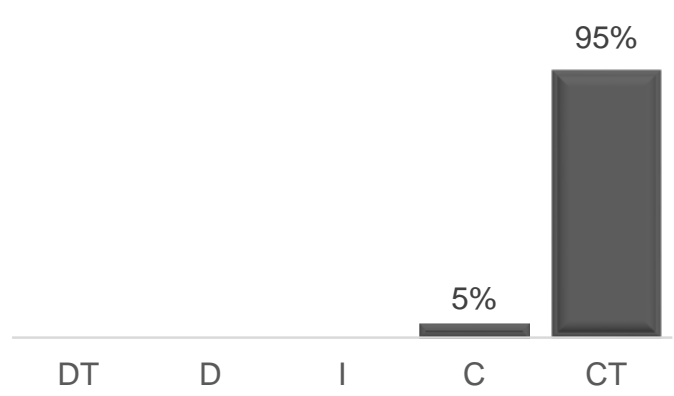

23. As legendas foram suficientes para o entendimento das imagens

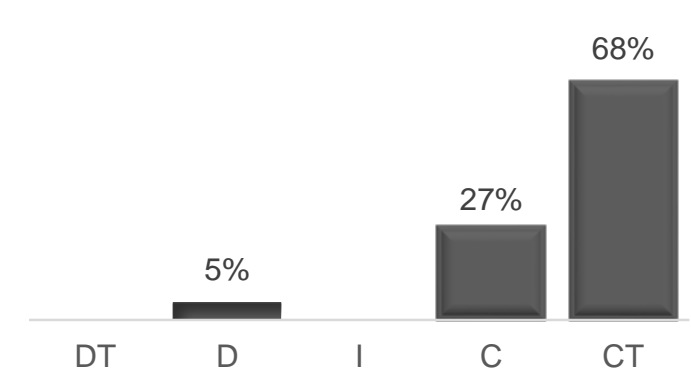

20. Senti-me motivado a aprofundar meu conhecimento a partir do vídeo

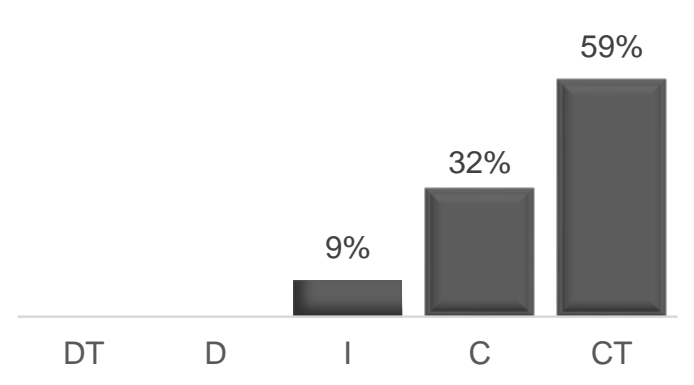

22. O som aplicado ao vídeo foi agradável

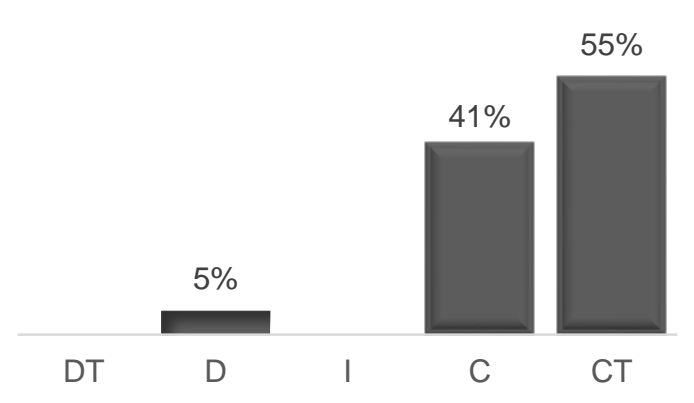

24. As legendas são dispensáveis para o entendimento da odontogênese

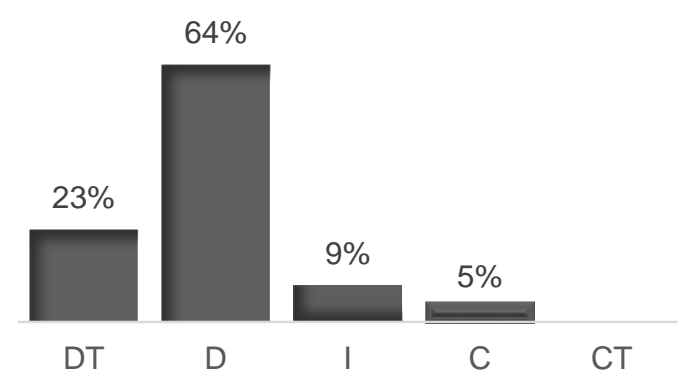

Figura 12 - Análise de item das afirmativas 19 a 24 (CT, concordo totalmente; C, concordo; I, indiferente; D, discordo; DT, discordo totalmente). 
25. A fase do sino foi bem desenvolvida pelo vídeo

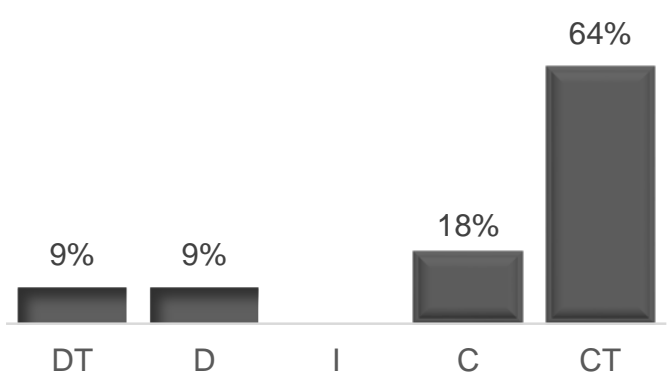

27. A fase de capuz foi facilmente entendida por mim

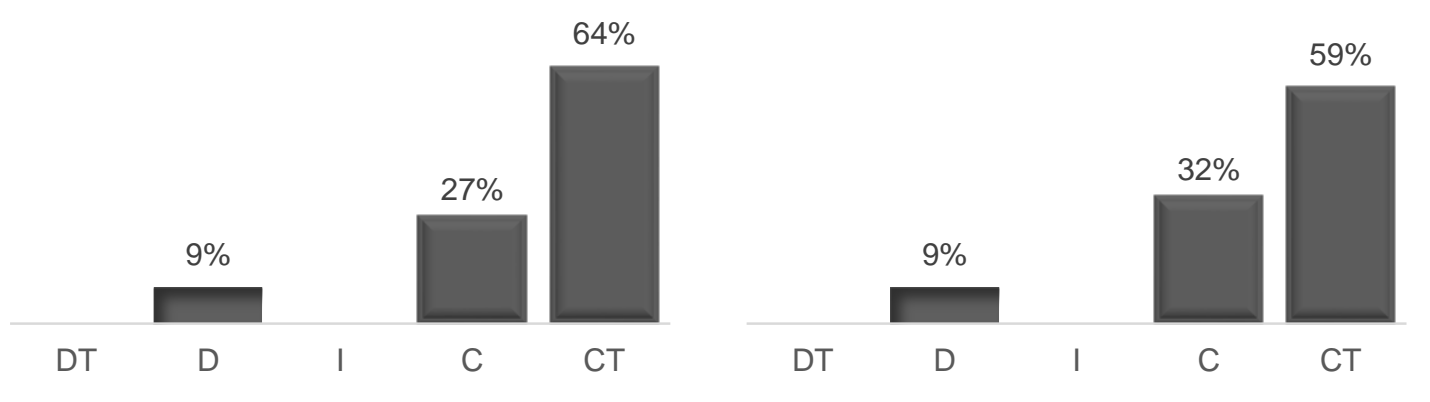

26. A fase de botão foi bem explicada
28. A fase incial da raiz foi bem retratada pelo vídeo
$64 \%$

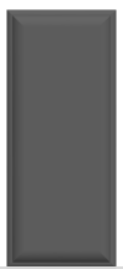

CT
29. O vídeo pode ser aplicado a estudantes de odontologia em qualquer fase da graduação e pósgraduação

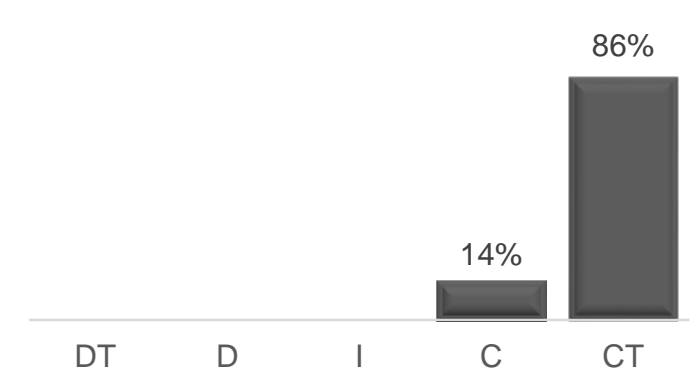

30. Tenho acesso ao material semelhante para o processo de ensino e aprendizado da odontogênese

$$
55 \%
$$

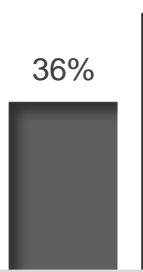

DT

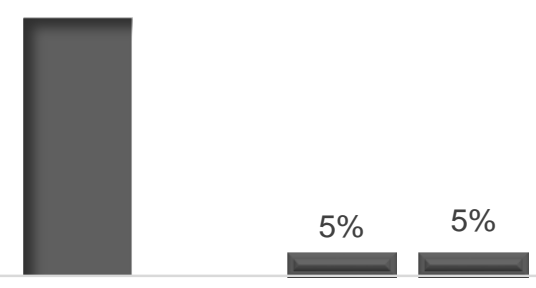

C

Figura 13 - Análise de item das afirmativas 25 a 30 (CT, concordo totalmente; C, concordo; I, indiferente; D, discordo; DT, discordo totalmente). 
31. Considero que esse material didático tem um alto padrão de qualidade

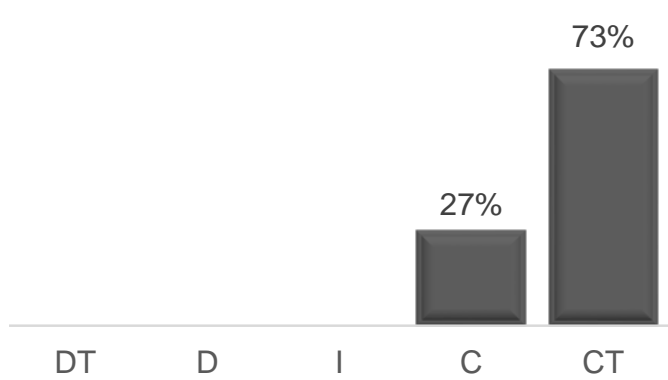

33. Esse material pode ser utilizado para orientar a comunidade

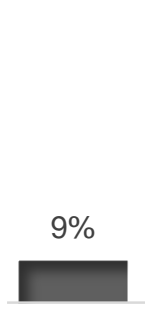

DT
$50 \%$

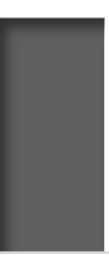

D

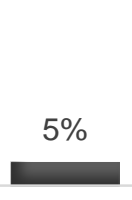

I
C

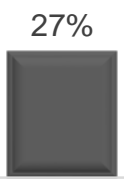

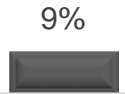

CT
35. O vídeo pode ser utilizado por profissionais de outras áreas da saúde

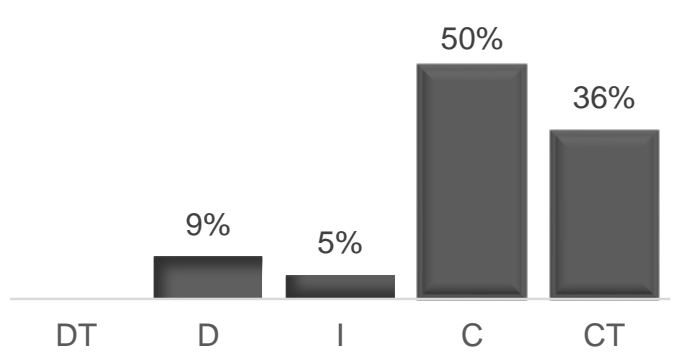

32. Esse material didático pode ser utilizado para formação de profissionais da atenção primária

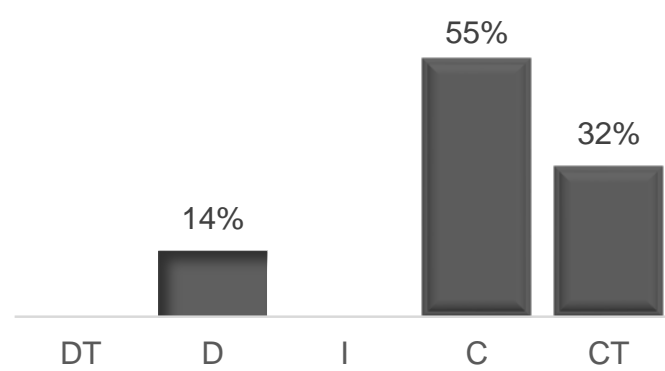

34. A linguagem utilizada permite a compreensão de estudantes de graduação

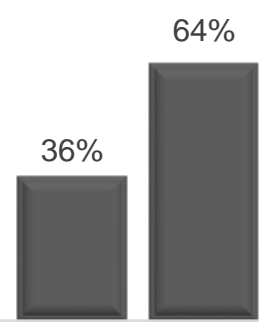

DT

C

CT

Figura 14 - Análise de item das afirmativas 31 a 36 (CT, concordo totalmente; C, concordo; I, indiferente; D, discordo; DT, discordo totalmente). 
37. Considero essa ferramenta útil para a prática docente

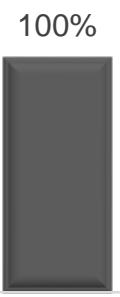

DT

D I

C

CT
38. O uso desse material didático requer capacitação prévia do docente

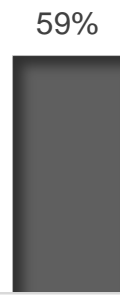

DT

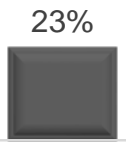

C

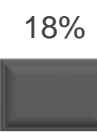

CT

39. Sinto-me apto a trabalhar com novas tecnologias educacionais

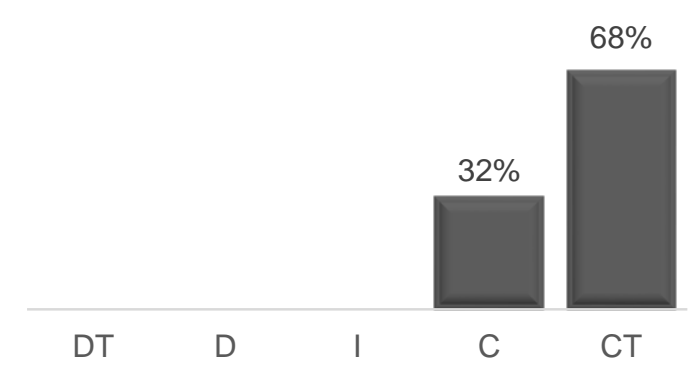

Figura 15 - Análise de item das afirmativas 37 a 39 (CT, concordo totalmente; C, concordo; I, indiferente; D, discordo; DT, discordo totalmente). 
Tabela 1 - Análise de resposta por frequência

\begin{tabular}{|c|c|c|c|c|c|}
\hline Afirmações & $\begin{array}{l}\text { DT } \\
\%\end{array}$ & $\begin{array}{l}\mathbf{D} \\
\%\end{array}$ & $\%$ & $\begin{array}{l}\mathbf{C} \\
\%\end{array}$ & $\begin{array}{l}\mathbf{C T} \\
\%\end{array}$ \\
\hline $\begin{array}{l}\text { 1.O vídeo permitiu o meu entendimento de todas as fases da } \\
\text { odontogênese. }\end{array}$ & & & & 32 & 68 \\
\hline $\begin{array}{l}\text { 2. A narração mostrou-se necessária ao meu entendimento } \\
\text { do tema. }\end{array}$ & & & 5 & 27 & 68 \\
\hline 3.Os movimentos das cenas foram esclarecedores para mim. & & & & 41 & 59 \\
\hline $\begin{array}{l}\text { 4. As cores apresentadas estão de acordo com a norma } \\
\text { internacional. }\end{array}$ & & & 14 & 36 & 50 \\
\hline 5.A iluminação do vídeo foi apropriada. & & & 5 & 23 & 73 \\
\hline $\begin{array}{l}\text { 6. O uso de imagens tridimensionais auxiliou o meu } \\
\text { entendimento do tema. }\end{array}$ & & & & & 100 \\
\hline $\begin{array}{l}\text { 7. Considero a odontogênese uma temática bastante } \\
\text { simples. }\end{array}$ & 9 & 68 & & 18 & 5 \\
\hline $\begin{array}{l}\text { 8. O conhecimento da odontogênese é fundamental para um } \\
\text { odontólogo. }\end{array}$ & & & 14 & 36 & 50 \\
\hline $\begin{array}{l}\text { 9. O formato de vídeo de animação facilitou o meu } \\
\text { aprendizado. }\end{array}$ & & & & 14 & 86 \\
\hline 10. O conteúdo apresentado está atualizado. & & & 5 & 32 & 64 \\
\hline 11. A visualização do vídeo foi possível no meu computador. & & & & 14 & 86 \\
\hline $\begin{array}{l}\text { 12. O meu acesso ao ambiente virtual de aprendizado foi } \\
\text { fácil. }\end{array}$ & & 5 & & 36 & 59 \\
\hline 13. As legendas estão de acordo com as imagens. & & 9 & & 27 & 64 \\
\hline $\begin{array}{l}\text { 14. As indicações nas imagens facilitaram a minha } \\
\text { compreensão. }\end{array}$ & & & & 23 & 77 \\
\hline $\begin{array}{l}\text { 15. O tempo do vídeo é suficiente para um bom } \\
\text { entendimento do assunto. }\end{array}$ & & 5 & 5 & 59 & 32 \\
\hline $\begin{array}{l}\text { 16. O vídeo apresentou corretamente a sequência da } \\
\text { odontogênese. }\end{array}$ & & 5 & & 14 & 82 \\
\hline 17. As imagens são norteadas pela teoria. & & & & 23 & 77 \\
\hline $\begin{array}{l}\text { 18. A linguagem utilizada permitiu minha compreensão sobre } \\
\text { a odontogênse. }\end{array}$ & & & & 32 & 68 \\
\hline 19. A narração do vídeo foi agradável. & 5 & 5 & 5 & 32 & 55 \\
\hline $\begin{array}{l}\text { 20. Senti-me motivado a aprofundar meu conhecimento a } \\
\text { partir do vídeo. }\end{array}$ & & & 9 & 32 & 59 \\
\hline
\end{tabular}


conclusão

\begin{tabular}{|c|c|c|c|c|c|}
\hline Afirmações & $\begin{array}{l}\text { DT } \\
\%\end{array}$ & $\begin{array}{l}\mathrm{D} \\
\%\end{array}$ & $\begin{array}{l}1 \\
\%\end{array}$ & $\begin{array}{l}\mathrm{C} \\
\%\end{array}$ & $\begin{array}{r}\text { CT } \\
\%\end{array}$ \\
\hline $\begin{array}{l}\text { 21. Considero que o vídeo pode facilitar o aprendizado sobre } \\
\text { o tema. }\end{array}$ & & & & 5 & 95 \\
\hline $\begin{array}{l}\text { 23. As legendas foram suficientes para o entendimento das } \\
\text { imagens. }\end{array}$ & & 5 & & 27 & 68 \\
\hline $\begin{array}{l}\text { 24. As legendas são dispensáveis para o entendimento da } \\
\text { odontogênese. }\end{array}$ & 23 & 64 & 9 & 5 & \\
\hline 25. A fase do sino foi bem desenvolvida pelo vídeo. & 9 & 9 & & 18 & 64 \\
\hline 26. A fase de botão foi bem explicada. & & 5 & & 32 & 64 \\
\hline 27. A fase de capuz foi facilmente entendida por mim. & & 9 & & 27 & 64 \\
\hline 28. A fase inicial da raiz foi bem retratada pelo vídeo. & & 9 & & 32 & 59 \\
\hline $\begin{array}{l}\text { 29. O vídeo pode ser aplicado a estudantes de odontologia } \\
\text { em qualquer fase da graduação e pós-graduação }\end{array}$ & & & & 14 & 86 \\
\hline $\begin{array}{l}\text { 30. Tenho acesso ao material semelhante para o processo } \\
\text { de ensino e aprendizado da odontogênese. }\end{array}$ & 36 & 55 & & 5 & 5 \\
\hline $\begin{array}{l}\text { 31. Considero que esse material didático tem um alto padrão } \\
\text { de qualidade. }\end{array}$ & & & & 27 & 73 \\
\hline $\begin{array}{l}\text { 32. Esse material didático pode ser utilizado para formação } \\
\text { de profissionais da atenção primária. }\end{array}$ & & 14 & & 55 & 32 \\
\hline $\begin{array}{l}\text { 33. Esse material pode ser utilizado para orientar a } \\
\text { comunidade. }\end{array}$ & 9 & 50 & 5 & 27 & 9 \\
\hline $\begin{array}{l}\text { 34. A linguagem utilizada permite a compreensão de } \\
\text { estudantes de graduação. }\end{array}$ & & & & 36 & 64 \\
\hline $\begin{array}{l}\text { 35. O vídeo pode ser utilizado por profissionais de outras } \\
\text { áreas da saúde. }\end{array}$ & & 9 & 5 & 50 & 36 \\
\hline $\begin{array}{l}\text { 36. Ter contato com essa tecnologia durante a minha } \\
\text { graduação teria facilitado meu entendimento sobre o tema. }\end{array}$ & & & & 5 & 95 \\
\hline 37. Considero essa ferramenta útil para a prática docente. & & & & & 100 \\
\hline $\begin{array}{l}\text { 38. O uso desse material didático requer capacitação prévia } \\
\text { do docente. }\end{array}$ & & 59 & & 23 & 18 \\
\hline $\begin{array}{l}\text { 39. Sinto-me apto a trabalhar com novas tecnologias } \\
\text { educacionais. }\end{array}$ & & & & 32 & 68 \\
\hline
\end{tabular}


Após esta análise inicial, as respostas foram alocadas em dois grupos, sendo o primeiro correspondente às respostas "Concordo totalmente" e "Concordo", que expressam uma percepção positiva com relação ao material construído e o segundo grupo correspondente às respostas "Indeferente", "Discordo" e "Discordo totalmente", que expressam uma percepção negativa com relação ao material construído (Tabela 2).

Tabela 2 - Análise da percepção positiva e negativa dos 22 validadores de acordo com suas respostas ao questionário de validação do objeto de aprendizagem.

\begin{tabular}{ccc}
\hline \multirow{2}{*}{ Afirmações } & Percepção & Percepção \\
& Positiva & Negativa \\
& CT/C $(\%)$ & l/D/DT $(\%)$ \\
\hline
\end{tabular}

1.0 vídeo permitiu o meu entendimento de todas as fases da odontogênese.

$22(100)$

2. A narração mostrou-se necessária ao meu entendimento do tema.

$21(95) \quad 1(5)$

3.Os movimentos das cenas foram esclarecedores para mim.

$22(100)$

4. As cores apresentadas estão de acordo com a norma internacional.

19 (86) $3(14)$

5.A iluminação do vídeo foi apropriada.

$21(95) \quad 1(5)$

6. O uso de imagens tridimensionais auxiliou o meu entendimento do tema.

$22(100)$

7. Considero a odontogênese uma temática bastante simples.

$5(23) \quad 17(77)$

8. O conhecimento da odontogênese é fundamental para um odontólogo.

$22(100)$

9. O formato de vídeo de animação facilitou o meu aprendizado.

$22(100)$

10. O conteúdo apresentado está atualizado.

$21(95) \quad 1(5)$

11. A visualização do vídeo foi possível no meu computador. 22 (100)

12. O meu acesso ao ambiente virtual de aprendizado foi fácil.

$21(95) \quad 1(5)$

13. As legendas estão de acordo com as imagens.

$20(91) \quad 2(9)$

14. As indicações nas imagens facilitaram a minha compreensão.

$22(100)$

15. O tempo do vídeo é suficiente para um bom entendimento do assunto.

$20(91) \quad 2(9)$ 


\begin{tabular}{|c|c|c|}
\hline Afirmações & $\begin{array}{l}\text { Percepção } \\
\text { Positiva } \\
\text { CT/C (\%) } \\
\end{array}$ & $\begin{array}{l}\text { Percepção } \\
\text { Negativa } \\
\text { I/D/DT (\%) }\end{array}$ \\
\hline $\begin{array}{l}\text { 16. O vídeo apresentou corretamente a sequência da } \\
\text { odontogênese. }\end{array}$ & $22(100)$ & \\
\hline 17. As imagens são norteadas pela teoria. & $21(95)$ & $1(5)$ \\
\hline $\begin{array}{l}\text { 18. A linguagem utilizada permitiu minha compreensão } \\
\text { sobre a odontogênse. }\end{array}$ & $22(100)$ & \\
\hline 19. A narração do vídeo foi agradável. & $19(86)$ & $3(14)$ \\
\hline $\begin{array}{l}\text { 20. Senti-me motivado a aprofundar meu conhecimento a } \\
\text { partir do vídeo. }\end{array}$ & $21(95)$ & $1(5)$ \\
\hline $\begin{array}{l}\text { 21. Considero que o vídeo pode facilitar o aprendizado } \\
\text { sobre o tema. }\end{array}$ & $22(100)$ & \\
\hline 22. O som aplicado ao vídeo foi agradável. & $5(23)$ & $17(77)$ \\
\hline $\begin{array}{l}\text { 23. As legendas foram suficientes para o entendimento das } \\
\text { imagens. }\end{array}$ & $22(100)$ & \\
\hline $\begin{array}{l}\text { 24. As legendas são dispensáveis para o entendimento da } \\
\text { odontogênese. }\end{array}$ & $22(100)$ & \\
\hline 25. A fase do sino foi bem desenvolvida pelo vídeo. & $21(95)$ & $1(5)$ \\
\hline 26. A fase de botão foi bem explicada. & $22(100)$ & \\
\hline 27. A fase de capuz foi facilmente entendida por mim. & $21(95)$ & $1(5)$ \\
\hline 28. A fase inicial da raiz foi bem retratada pelo vídeo. & $20(91)$ & $2(9)$ \\
\hline
\end{tabular}

29. O vídeo pode ser aplicado a estudantes de odontologia em qualquer fase da graduação e pós-graduação

30. Tenho acesso ao material semelhante para o processo de ensino e aprendizado da odontogênese.

31. Considero que esse material didático tem um alto padrão de qualidade.

32. Esse material didático pode ser utilizado para formação de profissionais da atenção primária.

33. Esse material pode ser utilizado para orientar a comunidade.

34. A linguagem utilizada permite a compreensão de estudantes de graduação. 
conclusão

Afirmações

35. O vídeo pode ser utilizado por profissionais de outras áreas da saúde.

$19(86) \quad 3(14)$

36. Ter contato com essa tecnologia durante a minha graduação teria facilitado meu entendimento sobre o tema.

37. Considero essa ferramenta útil para a prática docente. $22(100)$

38. O uso desse material didático requer capacitação prévia do docente.

$9(41) \quad 13(59)$

39. Sinto-me apto a trabalhar com novas tecnologias educacionais.

$22(100)$

A análise mostrou unanimidade de percepção positiva em vários itens do instrumento de validação, destacando as afirmativas relacionadas aos movimentos das cenas, entendimento de todas as fases da odontogênese, assim como na questão se o uso de imagens tridimensionais e animação auxiliaram o entendimento e aprendizado do tema. De acordo com os validadores, ter contato com essa tecnologia durante a graduação teria facilitado o entendimento sobre o tema. Eles consideram a ferramenta útil para a prática docente, além de estarem aptos a trabalhar com as novas tecnologias educacionais.

Das percepções negativas, $91 \%$ dos validadores não tem acesso ao material semelhante para o processo de ensino e aprendizado da odontogênese; $77 \%$ não acham uma temática simples e $54 \%$ acreditam que devido a sua complexidade, este objeto de aprendizagem não serve para orientar a comunidade.

Não foi possível obter uma análise fatorial devido ao perfil da amostra desse estudo resultando em um número de participantes restrito, mas que satisfaziam as características dessa validação. Por isso, a pesquisadora analisou os dados coletados por características significativas do instrumento da coleta. 
A análise dos itens conteúdo; design e imagens; apresentação e layout; computação gráfica 3D e animação; som, narração; e, por fim, roteiro foram validados com escores de zero a dez, de acordo com a opinião dos validadores, representados em percentagem.

1. Conteúdo

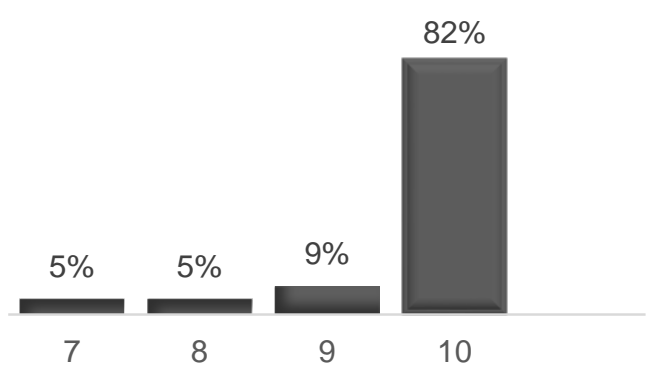

3. Apresentação/ Layout

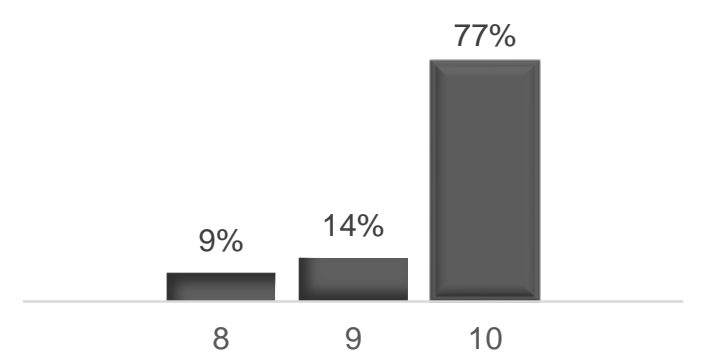

4. Computação gráfica $3 \mathrm{D}$ animação

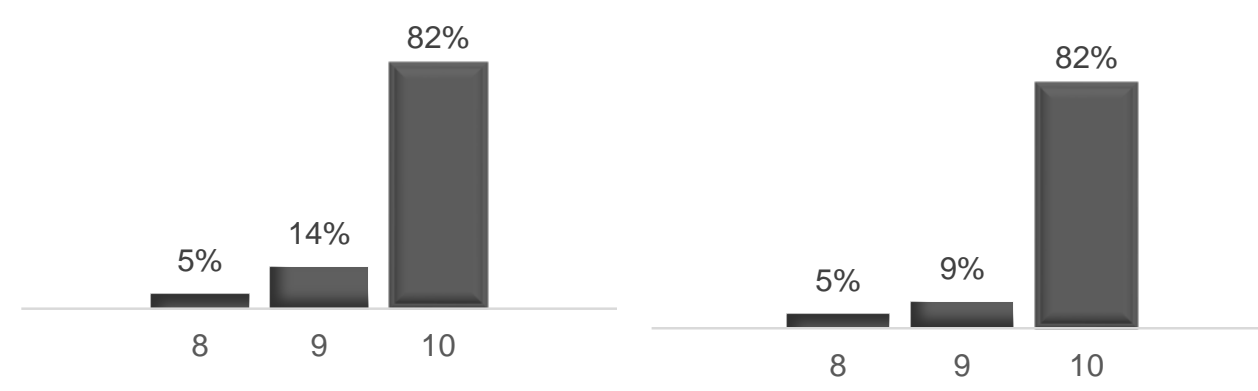

Figura 16 - Análise das respostas de zero a dez para conteúdo; design e imagens; apresentação e layout; computação gráfica 3D e animação 
5. Som

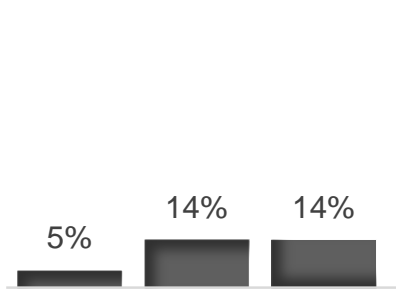

6

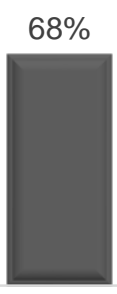

10

6. Narração

\section{Roteiro}

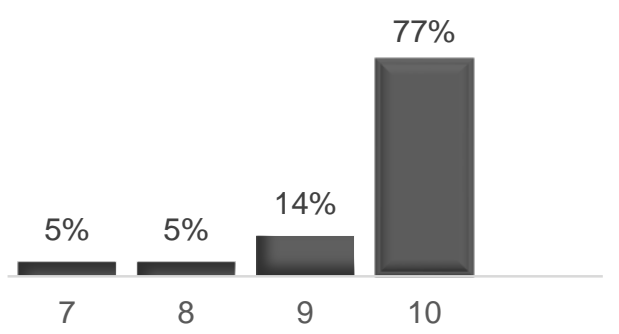

Figura 17 - Análise das respostas de zero a dez para som; narração e por fim roteiro

As variáveis de conteúdo, apresentação/layout, computação gráfica 3D/animação foram avaliados com maior porcentagem na nota 10, 82\%; 82\%; $86 \%$ respectivamente. As variáveis narração e som tiveram maiores discrepâncias de avaliação entre os validadores, sendo estas duas variáveis as únicas com ponderações com nota abaixo de sete (5\%) (Tabela3). 
Tabela 3 - Notas de zero a dez atribuídas ao objeto de aprendizagem de acordo com as sete variáveis

\begin{tabular}{|c|c|c|c|c|c|c|c|}
\hline \multirow[b]{2}{*}{ Variaveis } & \multirow[b]{2}{*}{3} & \multirow[b]{2}{*}{5} & \multicolumn{4}{|c|}{$\begin{array}{c}\text { Total validadores }(\mathrm{N}=22) \\
\mathrm{N}(\%)\end{array}$} & \multirow[b]{2}{*}{10} \\
\hline & & & 6 & 7 & 8 & 9 & \\
\hline 1.Conteúdo & & & & $1(5 \%)$ & $1(5 \%)$ & $2(9 \%)$ & $18(82 \%)$ \\
\hline 2. Design/imagem & & & & & $2(9 \%)$ & $3(14 \%)$ & $17(77 \%)$ \\
\hline $\begin{array}{l}\text { 3. Apresentação/ } \\
\text { layout }\end{array}$ & & & & & $1(5 \%)$ & $3(14 \%)$ & $18(82 \%)$ \\
\hline $\begin{array}{l}\text { 4. Computação } \\
\text { gráfica 3d - }\end{array}$ & & & & & $1(5 \%)$ & $2(9 \%)$ & $19(86 \%)$ \\
\hline 5. Som & & & $1(5 \%)$ & & $3(14 \%)$ & $3(14 \%)$ & $15(68 \%)$ \\
\hline 6. Narração & $1(5 \%)$ & $1(5 \%)$ & & $2(9 \%)$ & $2(9 \%)$ & $4(18 \%)$ & $12(55 \%)$ \\
\hline 7. Roteiro & & & & $1(5 \%)$ & $1(5 \%)$ & $3(14 \%)$ & $17(77 \%)$ \\
\hline
\end{tabular}

Quando perguntamos sobre a nota geral de zero a dez para o material didático odontogênese e a probabilidade de vir a utilizar esse material em uma prática docente, considerando zero nenhuma probabilidade e dez $100 \%$ de probabilidade, somente um validador afirmou que não utilizaria o material apresentado por estar aposentado e no momento sem atividade docente. 


\subsubsection{Análise dos dados qualitativos}

O questionário de validação continha três perguntas abertas acerca das forças e as fraquezas do objeto de aprendizagem e sugestões de aprimoramento. As respostas dessas perguntas foram analisadas pelo método de análise de conteúdo (47), o que permitiu identificar as seguintes categorias de forças: tecnologia, docência e conteúdo; e de fraquezas: narração e conteúdo.

A análise do perfil de forças do objeto de aprendizagem permitiu identificar as seguintes categorias de forças: tecnologia, docência e conteúdo.

Os professores afirmam que a utilização de tecnologias apresentadas na construção do material odontogênese é um incentivo ao aluno a estudar e facilita sobremaneira o entendimento sobre o assunto. Assunto esse de difícil compreensão e que vai de encontro aos locais não visualizáveis em livros textos. Outro ponto a ser destacado é a carência desse tipo de material didático nas faculdades de odontologia (Tabela 4). 
Tabela 4 - Análise qualitativa das respostas acerca de forças do material didático

\begin{tabular}{lll}
\hline Categoria & Item & Exemplo \\
\hline Tecnologia & $\begin{array}{l}\text { Visualização } \\
\text { tridimensional }\end{array}$ & $\begin{array}{l}\text { "Vai permitir muito o entendimento e visualização de todo o } \\
\text { processo da odontogênese, principalmente pela visão } \\
\text { tridimensional e dinâmica". }\end{array}$ \\
& "As imagens em terceira dimensão facilitam o aprendizado, \\
& juntamente com as legendas e a narração". \\
& "estímulo do aluno pela tecnologia; - acesso em qualquer hora \\
& e lugar; - informação qualificada e de fontes confiáveis; - \\
& possibilidade de difusão do conhecimento". \\
& "A visualização dinâmica tridimensional do processo de \\
& odontogênese auxilia e facilita sobremaneira o entendimento \\
& de um indivíduo da área da saúde. Qualidade didática e visual \\
& excelente". \\
& "Altamente explicativo. Incentiva a estudar mais o assunto. \\
& Imagens maravilhosas com acesso a locais impossíveis de se \\
& visualizar em um livro ou em uma lâmina. Alta qualidade. \\
& Realidade virtual educativa muito bem embasada". \\
& "As imagens em 3D facilitam a compreensão do conteúdo e \\
& podem aumentar a motivação dos estudantes".
\end{tabular}

Docência Aprendizagem

"Excelente material já há muitos anos gostaríamos de ter algo semelhante a isto para a prática docente na área de histologia as imagens facilitam muito o aprendizado do estudante"...

"Este material foi desenvolvido, executado e apresentado de maneira bastante didática, objetiva e clara, favorecendo e propiciando um melhor entendimento e aprendizado de toda a Odontogênese. Parabenizo a autora e demais envolvidos pela qualidade e relevância educativa do material apresentado". "O uso deste material nas faculdades de Odontologia tem potencial para facilitar e melhorar o processo de ensino e aprendizagem da Odontogênese".

"Gostaria de ter este material disponível para ser apresentado em aulas. Este material pode ser aplicado em vários momentos e em várias disciplinas sendo que o aluno vai melhorando e aperfeiçoando seu entendimento sobre $o$ assunto no decorrer do curso. O vocabulário é técnico e apropriado para o ensino na graduação e pós-graduação".

Conteúdo Odontogênese "Trata-se de um material didático interessante que aborda de forma leve e eficaz um tema relativamente complexo para os alunos de graduação e pós-graduação".

"A Odontogênese é um tema de difícil compreensão pelo aluno de odontologia".

"Quando se visualiza a dinâmica do processo de formação do dente fica muito mais claro e entendimento". 
A análise do perfil de fraquezas do objeto de aprendizagem permitiu identificar as seguintes categorias: narração e conteúdo.

Entre as fraquezas houve discordância dos validadores, um validador considerou a narrativa rápida e dessincronizado com a imagem que estava sendo apresentada, enquanto outro a considerou monótona, e os demais não a consideraram como uma fraqueza. Apenas um validador considerou que o conteúdo precisava ser aprofundado (Tabela 5). Mesmo sendo uma opinião da minoria dos validadores estes dois pontos foram revistos e aprimorados.

Tabela 5 - Análise qualitativa das respostas acerca de fraquezas do material didático

\begin{tabular}{|c|c|c|}
\hline Categoria & Item & Exemplo \\
\hline \multirow[t]{3}{*}{ Narração } & Terminologia & $\begin{array}{l}\text { "A terminologia usada na narração deve ser revista. Usar } \\
\text { SEMPRE o termo "'dentário"'" ou "'dentária"'" no lugar de } \\
\text { dental (anglicismo). Em alguns momentos a narração usa } \\
\text { dentário e em outros usa dental. Em português é mais correto } \\
\text { usar a forma "'"bucal"'" ao invés do termo oral (esse deve ser } \\
\text { restrito à oralidade, por exemplo prova escrita ou prova oral), } \\
\text { para designação anatômica, pela etimologia da nossa língua o } \\
\text { mais adequado é usar a terminologia "'"bucal"'", "'cavidade } \\
\text { bucal"'", "'"epitélio bucal"'". A forma oral também pode ser } \\
\text { considerada em português, como um anglicismo, já que na } \\
\text { língua inglesa utiliza- se raízes linguísticas diferentes do } \\
\text { português de origem latina". }\end{array}$ \\
\hline & Velocidade & "Narração rápida demais" \\
\hline & Tom & $\begin{array}{l}\text { "A narração poderia ser menos monótona; som muito baixo só } \\
\text { com o uso do volume total do notebook;; não gostei do início, } \\
\text { com as imagens do dente, polpa, coroa?? }\end{array}$ \\
\hline Conteúdo & Abrangência & $\begin{array}{l}\text { "No meu entendimento, o material didático carece de mais } \\
\text { informações sobre cada uma das fases da odontogênese, } \\
\text { sendo superficial em vários aspectos". } \\
\text { "...A formação da raiz foi menos enfatizada". }\end{array}$ \\
\hline
\end{tabular}


Segundo os validadores, o objeto de aprendizagem produzido sobre odontogênese, foi capaz de condensar os conteúdos mais significativos e relevantes podendo ser apresentado em aulas de graduação e pós-graduação. Tem outra vantagem a flexibilidade e potencial de difusão de uso desta produção intelectual. 


\section{DISCUSSÃO}

O presente trabalho apresentou o desenvolvimento de um objeto de aprendizagem com inovações tecnológicas com objetivo de facilitar o processo de ensino-aprendizagem em odontogênese.

As tecnologias digitais vêm potencializando o processo de ensinoaprendizagem a partir da elaboração de materiais didáticos, fazendo uso do som, cor e movimento, que proporcionam uma maior interatividade ${ }^{(51)}$. As animações, por exemplo, favorecem a compreensão de um novo conhecimento e torna 0 aprendizado mais significativo. Segundo Monteiro ${ }^{(52)}$ a teoria de Ausubel da aprendizagem significativa serve de alicerce para a idealização dos objetos de aprendizagem da educação interativa, mediados por tecnologia digital.

De acordo com Ausubel (53), para que ocorra uma aprendizagem significativa é necessário que o conteúdo ensinado se relacione com a estrutura cognitiva do aluno. Para que o estudante possa aprender, é necessário haver em sua estrutura cognitiva um conjunto de conceitos prévios, relevantes e inclusivos. Estes funcionam como pontos de ancoragem que possibilitam a conexão com a nova informação. Ao conjunto destes conceitos básicos, é dado nome de subsunçor, originado da palavra subsumer. Um subsunçor é, portanto, um conceito, ideia, ou proposição já existente na estrutura cognitiva do aluno, capaz de servir de "ancoradouro" para uma nova informação, de modo que ela adquira assim um significado para o indivíduo ${ }^{(54)}$.

Desta forma, o material instrucional mediado por tecnologia precisa estar organizado de forma lógica, em um processo de compreensão de conceitos, operando com múltiplas informações, qualitativamente diferenciadas, não só em relação aos seus conteúdos, mas também em relação à sua forma, modo e processo ${ }^{(52,55)}$. Além disso, os recursos da tecnologia permitem a modelagem de eventos reais que evoluem temporalmente, facilitando abstrair conceitos, além de exercitar a percepção, memória, linguagem e pensamentos ${ }^{(52,56)}$.

O processo de construção do objeto de aprendizagem odontogênese, tema deste estudo, baseou-se nos pressupostos da teoria Ausubeliana, 
utilizando formas, cores, movimentos, sons e textos para acessar os subsunçores existentes na estrutura cognitiva do estudante, público-alvo deste trabalho.

Para Audino e Nascimento(20), objetos de aprendizagem "são recursos digitais dinâmicos, interativos e reutilizáveis em diferentes ambientes de aprendizagem elaborados a partir de uma base tecnológica. Desenvolvidos com fins educacionais, eles cobrem diversas modalidades de ensino: presencial, híbrida ou a distância; diversos campos de atuação, educação formal, corporativa ou informal; e devem reunir várias características, como durabilidade, facilidade para atualização, flexibilidade, interoperabilidade, modularidade, portabilidade, entre outras. Eles ainda se apresentam como unidades auto consistentes de pequena extensão e fácil manipulação, passíveis de combinação com outros objetos educacionais ou qualquer outra mídia digital como imagens, vídeos, softwares e animações sendo reutilizados para a aprendizagem $^{(57,58)}$. O objeto de aprendizagem odontogênese traz a possibilidade de diversos usos direcionados aos diferentes públicos-alvo: estudantes de graduação, estudantes de pós-graduação, professores e profissionais da área de saúde e, por que não dizer, a população. Esta característica de flexibilidade foi ressaltada pelo grupo de professores que validaram o objeto de aprendizagem, uma vez que ele poderá ser utilizado de acordo com as necessidades dos estudantes e o estilo de cada docente. Este conceito de flexibilidade de objeto de aprendizagem corrobora aquele apresentado por Behar e colaboradores ${ }^{(59)}$.

O avanço tecnológico gerou uma grande mudança social com novas formas de agir, pensar, aprender e ser. Os alunos atualmente demonstram maior desenvoltura na utilização dos recursos tecnológicos ${ }^{(59)}$ que os pode auxiliar na organização de raciocínios, elaboração de estratégias de resolução de problemas, atenção e concentração. Segundo Tarouco ${ }^{(21)}$, o uso integrado de ferramentas de tecnologias de informação e multimídias são apontados como capazes de proporcionar melhorias significativas no processo ensinoaprendizagem. A tecnologia é um fator chave nessas mudanças, trazendo novas possibilidades para a educação ${ }^{(21)}$. A computação gráfica 3D surge neste 
contexto como aliada na construção de imagens precisas e dinâmicas que retratam moléculas, células, órgãos, músculos, ossos, tecidos e todos os demais componentes do organismo. O desenho digital, somado ao conhecimento científico, permite a visualização detalhada de processos fisiológicos e a compreensão destes processos, principalmente aqueles de difícil visualização em livros ou lâminas (13). O produto desta pesquisa esteve orientado pelas demandas desta nova geração, denominada de net generation ${ }^{(5)}$, oferecendo informações relevantes, de forma dinâmica, animada e acessível em formato atrativo e motivador.

Outro objetivo do presente estudo foi construir um processo validação para objeto de aprendizagem. Há na literatura exemplos de processos de validação de objeto de aprendizagem como aqueles descritos por Behar ${ }^{(60,61)} \mathrm{e}$ Souza (62). No entanto, poucos se remetem à validação de objetos de aprendizagem desenvolvidos com computação gráfica tridimensional. Neste sentido, apresentar um processo de validação de objeto de aprendizagem neste formato responde a uma demanda atual de educadores das mais diferentes áreas.

A seguir, são apresentados três exemplos de processos de validação descritos na literatura. Buscou-se destacar as metodologias utilizadas por eles para validação dos diversos objetos de aprendizagens a partir de análises qualitativa e quantitativa.

O ARQUEAD é um objeto de aprendizagem sobre Arquiteturas Pedagógicas para a Educação a Distância. Segundo a autora Behar, a arquitetura pedagógica é um sistema de premissas teóricas que representa, explica e orienta a forma como se aborda o currículo e que se concretiza nas práticas pedagógicas e nas interações professor-aluno-objeto de estudo/conhecimento. Este objeto foi construído no intuito de abordar as diferentes correntes pedagógicas, a utilização de funcionalidades, recurso e ferramentas de ambientes virtuais de aprendizagem. Sua utilização é destinada a situações de aprendizagem tanto na modalidade a distância como na presencial. Nesta abordagem, compreende-se que os objetos de aprendizagem favorecem uma nova concepção de aprendizagem, apoiada por computador, a 
qual caracteriza por promover a construção de conhecimento por meio da interação. O ARQUEAD foi validado no curso de extensão, intitulado "Oficina de Arquiteturas Pedagógicas para EAD", destinado a professores e tutores atuantes em cursos da Universidade Federal do Rio Grande do Sul. O curso foi desenvolvido por duas pesquisadoras do núcleo e participantes da equipe de construção deste objeto. O objetivo da validação foi verificar a qualidade dos recurso e referenciais do objeto em relação a estes requisitos, obtidos no curso de extensão. A validação se deveu pela coleta de dados em aulas, bate-papos, fórum, diário de bordo e webfolio inseridos no ambiente virtual de aprendizagem, onde, desse modo, os alunos interagiram de forma síncrona e assíncrona na modalidade a distância. Esses dados serviram para realizações de reflexões, debates e discussões sobre as características do ARQUEAD (39). Portanto, a metodologia de validação do objeto de aprendizagem ARQUEAD se deu por meio de uma pesquisa qualitativa, que é um método investigativo científico em que se busca o caráter subjetivo do objeto analisado, estudando as suas particularidades e experiências individuais.

Outro modelo de validação de objeto de aprendizagem foi descrito por Souza ${ }^{(62)}$, que apresentou uma pesquisa aplicada ao Ensino e Aprendizagem de Matemática do Ensino Médio, com a utilização do Objeto de Aprendizagem "Multiplicação de Matrizes" desenvolvido por meio da ferramenta Flash. Partindo disto, escreveu as etapas da sua construção, validação, seu potencial pedagógico e a tecnologia utilizada. A validação deste objeto de aprendizagem foi aplicada para nove professores de matemática em formação. Essa pesquisa, segundo o autor, caracterizou-se por um estudo de caso, que é um método utilizado na pesquisa qualitativa que apresenta como objetivo uma unidade, tema que possa ser analisado de maneira mais aprofundada, examinando detalhadamente um ambiente, uma situação, um sujeito ou um objeto. É uma forma de se fazer pesquisa investigativa de fenômenos atuais dentro de seu contexto real, no qual se podem coletar informações específicas e detalhadas, envolvendo o pesquisador, o comportamento de um sujeito ou grupo de sujeitos, diante de uma determinada situação. Diante disso, a coleta de dados baseou-se em observação direta não participante, porque os professores convidados não 
apresentaram dúvidas durante a exploração do objeto de aprendizagem; e em uma pesquisa quantitativa em que se utilizou um questionário contendo questões abertas e treze questões fechadas em escala do tipo Likert. Como resultado da validação, surgiram sugestões de reformulações do objeto de aprendizagem (62).

As autoras, Silva e Behar (61), apresentaram uma pesquisa acerca do desenvolvimento e da validação do objeto de aprendizagem: CompDig_EAD Competências Digitais no Contexto da EAD (ensino a distância). Este objeto de aprendizagem foi desenvolvido por uma equipe interdisciplinar, e teve como tema o mapeamento de competências digitais dos alunos no contexto da educação a distância, foi aplicado em uma disciplina de pós-graduação da Universidade Federal do Rio Grande do Sul. Com relação à validação do objeto, este se deu por meio de um questionário online. Tal instrumento foi composto por questões objetivas e dissertativas, somando seis questões ao total, focando sobre Conteúdo, Usabilidade/Interface e Didático/Pedagógico. Este questionário foi respondido por 24 alunos de diferentes formações, ou seja, de caráter interdisciplinar, de especialistas a pós-graduandos. Quanto ao perfil dos alunos em relação ao uso do computador e de navegação na internet, percebeu-se que havia níveis diferentes, ou seja, usuários iniciantes e avançados. Ao final da validação, destacaram pontos positivos e negativos quanto ao uso do objeto na disciplina e sugestões de alterações ${ }^{(61)}$.

Validar está para além de conferir a viabilidade de uma estratégia ou objeto educacional. Envolve a verificação de satisfação dos envolvidos como professores e alunos; e a análise do seu potencial pedagógico no que tange à assimilação do conteúdo e aprimoramento do objeto de aprendizagem por meio de pesquisa com especialistas da área. No presente estudo, a validação do objeto de aprendizagem odontogênese utilizou um processo na modelagem de peer review, ou seja, foi realizado por professores da mesma área da autora. Utilizou como ferramenta do processo um questionário online composto por questões objetivas e dissertativas. As questões objetivas respondidas em escala do tipo Likert foram submetidas a análises estatísticas descritivas e aquelas dissertativas, avaliadas a partir da técnica de análise de conteúdo de Bardin (44). A análise das respostas resultou na identificação de pontos fortes e pontos 
fracos. Segundo os respondentes do processo de validação, o uso do objeto de aprendizagem da odontogênese mediado por tecnologia, além de facilitar 0 acesso ao material em qualquer hora e lugar, é um incentivo ao aluno estudar mais o assunto, porque as imagens em 3D, as legendas e animações facilitam o aprendizado de um tema que, segundo estes validadores, é complexo.

Segundo os validadores, o vídeo da Odontogênese foi capaz de condensar os conteúdos mais significativos e relevantes, podendo ser apresentado em aulas de graduação e pós-graduação. Além disso, o mesmo pode ser aplicado em vários momentos e em várias disciplinas sendo que o aluno vai melhorando e aperfeiçoando seu entendimento no decorrer do curso, demonstrando assim sua flexibilidade de uso. A vantagem desta produção é sua flexibilidade e potencial de difusão de uso. Corroborando com Moran que afirma ser o formato digital de maior facilidade para difusão a nível global (2).

Observaram ainda que as cenas mostradas no objeto de aprendizagem permitem visualizar aspectos do processo não distinguíveis nos livros textos ou em lâminas. Outro ponto positivo foi o entendimento claro e concreto do processo da odontogênese destacando o design e conteúdo de excelente qualidade, altamente explicativo, que prende a atenção pela beleza das cenas.

Diante da análise das respostas, foi possível comprovar a carência de material semelhante nas instituições de ensino superior que oferecem cursos de graduação e pós-graduação em odontologia.

Os validadores tiveram uma visão muito mais positiva do que negativa a respeito do objeto de aprendizagem produzido. No entanto, apontaram alguns pontos fracos como, por exemplo, a narrativa. Em relação ao conteúdo, foi considerado adequado, porém com possibilidade de aprimoramento de alguns itens.

Outra possibilidade de validação futura para o objeto de aprendizagem do presente estudo é proceder a validação com um grupo de alunos. Os jovens de hoje são nativos digitais e desde muito cedo incorporam a tecnologia no seu cotidiano, desde jogos digitais até a formação de um rede social e busca de informações com autonomia. É necessário reconhecer as características dos 
nativos digitais em seu processo de aprendizagem. Sua aprendizagem é social, pois têm facilidade de jogar em grupos e formar equipes. Compartilham suas descobertas e dúvidas em comunidades de tal forma que a interação e comunicação entre eles cria um contexto propício para o "ensino entre pares e para a emergência de comunidades de aprendizagem”(6).

A produção educacional foco da presente tese de mestrado, que teve como base a utilização de ferramentas tecnológicas, serve de modelo para a modernização dos materiais educacionais e sua validação. Preenche também uma lacuna no ensino da odontologia. Este estudo demonstra a possibilidade de melhorar a compreensão sobre um tema a partir de uma produção intelectual, que apresenta conteúdos com recursos tecnológicos. Dialogando com as expectativas de uma nova geração de ofertas de conteúdo interativo, visualmente atrativo, de fácil compreensão e acesso, de uso flexível e que lhes permita reconstruções e participação ativa no processo de ensino aprendizagem. A metodologia de validação do objeto de aprendizagem apresentado neste trabalho também buscou excelência não somente na produção intelectual da construção do objeto de aprendizagem, como também na seleção de docentes, buscando aqueles que atuam na área da odontogênese e que pertençam a universidades de diferentes regiões brasileiras. 


\section{CONCLUSÃO}

O presente estudo teve como foco a construção de um objeto de aprendizagem sobre odontogênese e sua validação a partir do uso de ferramentas de tecnologia digital com propósito educacional.

Apresenta-se ao final deste processo um objeto de aprendizagem que traz uma síntese de informações, condensando conceitos relevantes apresentados de forma dinâmica.

Atende a diversos interesses de aprendizado, sendo adaptável a diferentes públicos, podendo contribuir com a formação de estudantes, pósgraduandos e profissionais da área de saúde.

Esta produção intelectual foi submetida a um processo de validação que contribuiu com o seu aprimoramento, demonstrando compromisso com a produção de material educacional de qualidade e atualizado.

Contribuiu desta forma com a produção de conhecimentos para a área pedagógica, odontológica e de tecnologia digital. 


\section{REFERÊNCIAS}

1. Miot HA, Paixão MP, Wen CL. Teledermatologia - Passado, presente e futuro. Anais Brasileiros de Dermatologia. 2005. p. 523-32.

2. Moran JM. Novas tecnologias e o re-encantamento do mundo. Tecnol Educ. 2008;23(126):1-7.

3. França G, Silva LM da, Santos LA, Vasconcelos PAC de. DESIGN INSTRUCIONAL: METODOLOGIAS, COMUNICAÇÃO, AFETIVIDADE E APRENDIZAGEM. InterSciencePlace [Internet]. 7 de abril de 2014 [citado 26 de abril de 2016];1(2).

4. Wen CL. Telemedicine, eHealth and Remote Care Systems. Global Health Informatics: How Information Technology Can Change Our Lives in a Globalized World. 2016. p. 168-94.

5. Prensky M. Digital Natives, Digital Immigrants Part 1. Horiz [Internet]. setembro de 2001 [citado 14 de fevereiro de 2017];9(5):1-6.

6. Pescador CM. TECNOLOGIAS DIGITAIS E AÇÕES DE APRENDIZAGEM DOS NATIVOS DIGITAIS. V Congresso Internacional de Filosofia e Educação. 2010. p. 10.

7. Bastos JRM, Peres SHCS CM. Educação em Saúde com enfoque em Odontologia e em Fonoaudiologia. - Google Search. Sao Paulo: Editora Santos; 2007. p. 19-20.

8. Tempski P. Avaliação da qualidade de vida do estudante de medicina e da influência exercida pela formação acadêmica [Internet]. Uma ética para quantos? 2008. Recuperadode:

ttp://www.ncbi.nlm.nih.gov/pubmed/15003161

9. Paixão MP. Modelo de educação a distância em hanseníase voltado para rede de detecção de casos e diagnóstico - Google Search [Internet]. 2008 [citado 27 de abril de 2016]. 
10. Alencar CF. Avaliação de conteúdos e objeto de aprendizagem da teleodontologia aplicado a anestesia e exodontia em odontopediatria. 2008.

11. Wen CL, Silveira PS, Azevedo RS, Bohm GMB. Internet discussion lists as an educational tool. J Telemed Telecare [Internet]. 2000 [citado 12 de janeiro de 2017];6(5):302-4. Recuperado de: http://jtt.sagepub.com/content/6/5/302.full.pdf

12. Miot H, Paixão $M$, Wen $C$. Teledermatology: past, present and future. An Bras Dermatol [Internet]. 2005 [citado 12 de janeiro de 2017];

Recuperado de: http://www.scielo.br/scielo.php?pid=S036505962005000600011\&script=sci_arttext\&tIng=es

13. Chao L. Telemedicina e Telessaúde - Um panorama no Brasil. Inform Pública [Internet]. 2008 [citado 12 de janeiro de 2017];10(2):07-15. Recuperado de:

http://www.ip.pbh.gov.br/ANO10_N2_PDF/telemedicina_telesaude.pdf

14. BRASIL M da E. Resolução Cne/Ces 3, De 19 De Fevereiro De 2002. Diário Of da União, Brasília [Internet]. 2002;1:1-5. Recuperado de: http://portal.mec.gov.br/cne/arquivos/pdf/CES032002.pdf

15. Sequeira É, Chao RS, José M, Moraes T, Haddad VK, Wen CL. Modelo de teleducação sobre cuidados com a saúde oral do idoso usuário de prótese total dental. Rev da ABENO @BULLET. 2013;13(2):2-12.

16. Wiley DA. Learning Object Design and Sequencing Theory. Learn Object Des Seq Theory. 2000;(June):142.

17. Wiley DA, Wiley DA. Learning object design and sequencing theory. 2000. 1-131 p.

18. Behar P. Constructing Pedagogical Models for E-Learning. Int J Adv Corp Learn [Internet]. 2011 [citado 22 de setembro de 2017];

19. Behar, Patricia Alejandra; Torrezzan, C A W; Ruckert AB. PEDESIGN: a construção de um objeto de aprendizagem baseado no design 
pedagógico. Novas Tecnol na Educ. 2008;6(2):1-10.

20. Audino DF, Nascimento R da S. OBJETOS DE APRENDIZAGEM DIÁLOGOS ENTRE CONCEITOS E UMA NOVA PROPOSIÇÃO APLICADA À EDUCAÇÃO. Rev Contemp Educ. 2012;5(10).

21. Tarouco L, Cunha S. Aplicação de teorias cognitivas ao projeto de objetos de aprendizagem. Novas Tecnol na Eduação. 2006;(Wiley 2002):1-9.

22. Behar PA, Behar PA, Passerino L, Bernardi M. Modelos Pedagógicos para Educação a Distância: pressupostos teóricos para a construção de objetos de aprendizagem. RENOTE [Internet]. 2010 [citado 12 de janeiro de 2017];5(2).

23. Mogali SR, Yeong WY, Kuan H, Tan J, Jit G, Tan S, et al. Evaluation by Medical Students of the Educational Value of Multi-Material and MultiColored Three-Dimensional Printed Models of the Upper Limb for Anatomical Education. 2017;0.

24. Anastasiou LDGC. Metodologia de ensino na universidade brasileira: elementos de uma trajetória. Temas e Textos da Educ Super. 2001;1-10.

25. Knowles M. The modern practice of adult education [Internet]. 1970 [citado 14 de fevereiro de 2017]. Recuperado de: http://www.hospitalist.cumc.columbia.edu/downloads/cc4_articles/Educati on Theory/Andragogy.pdf

26. Enns SC. Avaliação da percepção do ambiente de ensino e sua relação com a qualidade de vida em estudantes de medicina. 2014;152.

27. Cercone K. Characteristics of adult learners with implications for online learning design. AACE J [Internet]. 2008 [citado 14 de fevereiro de 2017]; Recuperado de:

http://anitacrawley.net/Resources/Articles/adultlearneronline.pdf

28. Ausubel D. - Aquisição e Retenção de Conhecimentos. 2000. 
29. Monteiro BDS, Cruz HP, Andrade M, Gouveia T. Metodologia de desenvolvimento de objetos de aprendizagem com foco na aprendizagem significativa. XVII Simpósio Informática na Educ [Internet]. 2006;(October):

30. Pelizzari A, Kriegl M, Baron M. Teoria da aprendizagem significativa segundo Ausubel. revista [Internet]. 2002 [citado 16 de janeiro de 2017]; Recuperado de: http://files.gpecea-usp.webnode.com.br/20000039374efd75e9b/MEQII-2013- TEXTOS COMPLEMENTARES- AULA 5.pdf

31. Freire P. Prefácio. Pedagogia da Autonomia - saberes necessários à prática educativa. 1996. 7-8 p.

32. Freire P. Educação e mudança [Internet]. 2014 [citado 15 de fevereiro de 2017].

33. Okada A, Barros D. Os estilos de coaprendizagem para as novas características da educação (3.0). 2013 [citado 11 de junho de 2015].

34. Keats. Challenges for Quality Assurance in an Education 3.0 world. Education. :1-8.

35. Guedes-Pinto AC, Bonecker MJS, Rodrigues CRMD, Crivello Junior O. Odontopediatria. Santos; 2011.

36. Katchburian E, Arana V. Histologia e embriologia oral : texto-atlascorrelações clínicas. Panamericana; 1999.

37. Nanci A. en cate: oral histology: development, structure and function. Nanci A, Ten Cate A Ten cate: oral histology : development, structure and function Missouri: Mosby; 2013. 2013. p. 122-64.

38. Moore, Keith L., T.V.N. Persaud MGT. Embriología Clínica [Internet]. Uma ética para quantos? 2014. 81-87 p. Recuperado de:

http://www.americanbanker.com/issues/179_124/which-city-is-the-nextbig-fintech-hub-new-york-stakes-its-claim-10683451.html\%5Cnhttp://www.ncbi.nlm.nih.gov/pubmed/15003161\%5Cnhttp://cid .oxfordjournals.org/lookup/doi/10.1093/cid/cir991\%5Cnhttp://www.scielo 
39. Behar P, Bernardi M, Silva K da. Arquiteturas Pedagógicas para a Educação a Distância: a construção e validação de um objeto de aprendizagem. Renote [Internet]. 2009; Recuperado de:

http://www.seer.ufrgs.br/renote/article/view/14088

40. Chao LW, Cestari TF, Bakos L, Oliveira MR, Miot H a, Zampese M, et al. Evaluation of an Internet-based teledermatology system. J Telemed Telecare [Internet]. 2003 [citado 15 de agosto de 2017];9 Suppl 1(Fig 3):S9-12. Recuperado de: http://journals.sagepub.com/doi/abs/10.1258/135763303322196169

41. Cramer $\mathrm{J}$ a. Principles of health-related quality of life: assessment in clinical trials. Epilepsia. 2002;43(9):1084-95.

42. Cronbach L. Coefficient alpha and the internal structure of tests, Psychometrika. Psychometrika. 1951;16(3):297-334.

43. Bland JM, Altman DG. Statistics Notes : Cronbach â€ $€^{\mathrm{TM}} \mathrm{s}$ Alpha. Br Med J. 1997;314(7080):22-3.

44. Bardin L. Análise do conteúdo. Lisboa: Edições 70. 1995.

45. Fallis A. A ANÁLISE DE CONTEÚDO NA PERSPECTIVA DE BARDIN. J Chem Inf Model. 2013;53(9):1689-99.

46. Turato ER. Tratado da Metodologia da Pesquisa Clínico-Qualitativa. Petrópolis: Editora Vozes. 2003.

47. Denzin N, Lincoln YS. O Planejamento da pesquisa qualitativa Teoria e Abordagens. Porto Alegre: Artmed. 2006.

48. Debus M. Manual para excelência en la investigación mediante grupos focales. Washington: Academy of Educational Development. 1997.

49. Katchburian E 1935-, Arana-Chavez VE. Histologia e embriologia oral : texto-atlas-correlações clínicas. Guanabara-Koogan; 2004.

50. Sullivan GM, Artino a R. Analyzing and interpreting data from likert-type scales. J Grad Med Educ [Internet]. 2013;5(4):541-2. Recuperado de: 
http://www.ncbi.nlm.nih.gov/pubmed/24454995

51. Scolari AT, Scolari AT, Bernardi G, Cordenonsi AZ. O Desenvolvimento do Raciocínio Lógico através de Objetos de Aprendizagem. RENOTE [Internet]. 2010 [citado 13 de janeiro de 2017];5(2). Recuperado de: http://www.seer.ufrgs.br/index.php/renote/article/view/14253

52. Monteiro ${ }^{1}$ B, Cruz H, Andrade M. Metodologia de desenvolvimento de objetos de aprendizagem com foco na aprendizagem significativa. 2006 [citado 18 de novembro de 2015]; Recuperado de:

http://www.researchgate.net/profile/Thiago_Gouveia/publication/2286661 35_Metodologia_de_desenvolvimento_de_objetos_de_aprendizagem_co m_foco_na_aprendizagem_significativa/links/0deec5231db87af17400000 $0 . p d f$

53. Ausubel D. 5-Aprendizagem Significativa. 2011 [citado 16 de janeiro de 2017]; Recuperado de:

http://www.academia.edu/download/43690730/aprendizagem_significativ a.pdf

54. Moreira M. Aprendizagem significativa: um conceito subjacente. Actas del II Encuentro Int sobre Aprendiz [Internet]. 1997 [citado 16 de janeiro de 2017]; Recuperado de:

http://www.if.ufrgs.br/asr/artigos/Artigo_ID16/v1_n3_a2011.pdf

55. Catapan A, FIALHO F. Pedagogia e tecnologia: a comunicação digital no processo pedagógico. Educ Porto Alegre PUC/ [Internet]. 2003;1-14. Recuperado de:

http://www.portalanpedsul.com.br/admin/uploads/2000/Educacao_e_form acao_de_professores/Mesa_Redonda_-

_Trabalho/07_10_51_1M1003.pdf

56. Castro C. COMPETÊNCIAS DIGITAIS PARA ENSINAR E APRENDER: FORMAR OU NÃO ? EIS A QUESTÃO. Challenges 2013 Aprender a qualquer hora e em qualquer lugar, Learn anything anityme anywhere. 2013;301-18. 
57. Audino DF, Nascimento R da S. OBJETOS DE APRENDIZAGEM DIÁLOGOS ENTRE CONCEITOS E UMA NOVA PROPOSIÇÃO APLICADA À EDUCAÇÃO. Rev Contemp Educ. 2012;5(10).

58. Ritzhaupt AD. Learning object systems and strategy: a description and discussion. Interdiscip J E-Learning Learn Objects [Internet]. 2010;6:21738. Recuperado de:

http://go.galegroup.com/ps/i.do?id=GALE\%7CA247740285\&v=2.1\&u=mli n_b_umass\&it=r\&p=AONE\&sw=w\%5Cnhttp://go.galegroup.com.ezproxy.I ib.umb.edu/ps/i.do?id=GALE\%7CA247740285\&v=2.1\&u=mlin_b_umass\& $\mathrm{it}=\mathrm{r} \& \mathrm{p}=\mathrm{AONE} \& \mathrm{sw}=\mathrm{w}$

59. Behar P A, Passerino L, Bernardi M. Modelos Pedagógicos para Educação a Distância: pressupostos teóricos para a construção de objetos de aprendizagem. RENOTE [Internet]. 2010 [citado 12 de janeiro de 2017];5(2). Recuperado de:

http://www.seer.ufrgs.br/index.php/renote/article/view/14242

60. Behar $\mathrm{P}$, Leite $\mathrm{S}$. The virtual learning environment ROODA: an institutional project of long distance education. J Sci Educ Technol [Internet]. 2006 [citado 22 de setembro de 2017]; Recuperado de: http://link.springer.com/article/10.1007/s10956-006-9002-x

61. Silva KK da, Behar PA. Do desenvolvimento a validação do objeto de aprendizagem CompDig_EAD Competências Digitais no Contexto da EAD. An temporários do LACLO 2015. 2015;10(1):197.

62. Souza PDA. Um Estudo da Construção e Validação do Objeto de Aprendizagem Multiplicação de Matrizes. 2014;147-53.

63. Tempski P, Martins MA. Team Based Learning "Eu aprendo, você aprende e nós aprendemos juntos" [apostila]. In: Educação na Saúde para Preceptores do SUS do Instituto de Ensino e Pesquisa do Hospital Sirio-Libanês, São Paulo, 2014.

www.projetohomemvirtual.org.br 


\section{ANEXOS}

Anexo I: Termo de consentimento livre e esclarecido eletrônico

TERMO DE CONSENTIMENTO LIVRE E ESCLARECIDO

\section{DADOS DE IDENTIFICAÇÃO}

1. NOME

DOCUMENTO DE IDENTIDADE №

SEXO M ŽF Ž

DATA NASCIMENTO ........................

ENDEREÇO

№ APTO

BAIRRO

CIDADE

CEP

TELEFONES (......)

2. RESPONSÁVEL LEGAL

NATUREZA (grau de parentesco, tutor, curador etc.)

DOCUMENTO DE IDENTIDADE

SEXO: $M \square F \square$

DATA NASCIMENTO.:

/.......

ENDEREÇO:

№

APTO:

BAIRRO:

CIDADE:

CEP:

TELEFONE: DDD(

..). 


\section{DADOS SOBRE A PESQUISA CIENTÍFICA}

1. TÍTULO DO PROTOCOLO DE PESQUISA: Odontogênese: construção e validação de um objeto de aprendizagem inovador

2. PESQUISADOR: Rosângela Suetugo Chao

CARGO/FUNÇÃO: Cirurgiã-dentista

INSCRIÇÃO CONSELHO REGIONAL № (CROSP): 33.015

UNIDADE DO HCFMUSP: Disciplina de Clínica Médica - Departamento de Clínica Médica.

3. AVALIAÇÃO DO RISCO DA PESQUISA: O projeto envolve material educativo e não submete seres humanos a riscos.

4. DURAÇÃO DA PESQUISA: 12 meses.

O Sr (a) está sendo convidado (a) como voluntário (a) a participar neste estudo cujo objetivo é validar a construção de um objeto educacional de aprendizagem sobre Odontogênese, elaborado para os docentes, discentes e profissionais da área de saúde. O Senhor (a) participará de um processo de validação de material educacional via website (internet). Após o contato com esse material fará uma análise crítica e sistematizada por meio de questionário eletrônico.

1. Todos os participantes estão livres para esclarecer quaisquer dúvidas que possam surgir a respeito deste projeto. Se tiver alguma consideração ou dúvida entre em contato com a pesquisadora Rosângela Suetugo Chao ou com o orientador Profa. Dra. Patricia Tempski da Disciplina de Clínica Médica - FMUSP Av. Dr. Arnaldo, 455 sala 1109, São Paulo - SP, email: rosangela@telemedicina.fm.usp.br - Telefone para contato: (0xx11) 3061-7495.

2. Fica confirmado o direito de todos os participantes de desistir de participar deste projeto qualquer momento, sem qualquer prejuízo. 
3. Os resultados e o andamento desta pesquisa estão abertos a todos os participantes, a qualquer momento. O nome e dados particulares não serão divulgados, garantindo sua privacidade.

4. Por ser um projeto educacional, não prevê riscos à saúde dos participantes.

5. Não haverá pagamentos ou qualquer tipo de vantagem ao participante.

Declaro não receber qualquer tipo de remuneração pela minha participação.

Declaro que, após convenientemente esclarecido pelo pesquisador e ter entendido o que me foi explicado, concordo em participar voluntariamente desta Pesquisa.

Data

Assinatura do participante

(Somente para o responsável do projeto)

Declaro que obtive de forma apropriada e voluntária o Consentimento Livre e Esclarecido deste participante.

Data 1

Assinatura do responsável pelo estudo 
Anexo II: Questionário de Validação do Objeto de Aprendizagem.

PROCESSO DE VALIDAÇÃO DO MATERIAL DIDÁTICO - ODONTOGÊNESE

Nome do avaliador:

Titulação:

Área de atuação:

Tempo de atuação:

Você está participando de um processo de validação de material didático sobre odontogênese. Reconhecemos sua formação e competência nessa área e entendemos que sua opinião acerca desse material pode em muito contribuir com o seu aprimoramento.

Garantimos a confidencialidade e o anonimato das suas respostas.

Por favor, responda as afirmações abaixo escolhendo a alternativa que considerar mais apropriada.

DT -Discordo Totalmente

D- Discordo

I - Indiferente

C - Concordo

CT - Concordo totalmente 


\begin{tabular}{|c|c|c|c|c|c|}
\hline \multirow{2}{*}{1.0 vídeo permitiu o meu entendimento de todas as fases da odontogênese. } & DT & D & $\mathbf{I}$ & $\mathbf{C}$ & CT \\
\hline & & & & & \\
\hline 2. A narração mostrou-se necessária ao meu entendimento do tema. & & & & & \\
\hline 3.Os movimentos das cenas foram esclarecedores para mim. & & & & & \\
\hline 4. As cores apresentadas estão de acordo com a norma internacional. & & & & & \\
\hline 5.A iluminação do vídeo foi apropriada. & & & & & \\
\hline 6. O uso de imagens tridimensionais auxiliou o meu entendimento do tema. & & & & & \\
\hline 7. Considero a odontogênese uma temática bastante simples. & & & & & \\
\hline 8. O conhecimento da odontogênese é fundamental para um odontólogo. & & & & & \\
\hline 9. O formato de vídeo de animação facilitou o meu aprendizado. & & & & & \\
\hline 10. O conteúdo apresentado está atualizado. & & & & & \\
\hline 11. A visualização do vídeo foi possível no meu computador. & & & & & \\
\hline 12. O meu acesso ao ambiente virtual de aprendizado foi fácil. & & & & & \\
\hline 13. As legendas estão de acordo com as imagens. & & & & & \\
\hline 14. As indicações nas imagens facilitaram a minha compreensão. & & & & & \\
\hline 15. O tempo do vídeo é suficiente para um bom entendimento do assunto. & & & & & \\
\hline 16. O vídeo apresentou corretamente a sequência da odontogênese. & & & & & \\
\hline 17. As imagens são norteadas pela teoria. & & & & & \\
\hline 18. A linguagem utilizada permitiu minha compreensão sobre a odontogênse. & & & & & \\
\hline 19. A narração do vídeo foi agradável. & & & & & \\
\hline 20. Senti-me motivado a aprofundar meu conhecimento a partir do vídeo. & & & & & \\
\hline 21. Considero que o vídeo pode facilitar o aprendizado sobre o tema. & & & & & \\
\hline 22. O som aplicado ao vídeo foi agradável. & & & & & \\
\hline 23. As legendas foram suficientes para o entendimento das imagens. & & & & & \\
\hline 24. As legendas são dispensáveis para o entendimento da odontogênese. & & & & & \\
\hline 25. A fase do sino foi bem desenvolvida pelo vídeo. & & & & & \\
\hline 26. A fase de botão foi bem explicada. & & & & & \\
\hline 27. A fase de capuz foi facilmente entendida por mim. & & & & & \\
\hline 28. A fase inicial da raiz foi bem retratada pelo vídeo. & & & & & \\
\hline $\begin{array}{l}\text { 29. O vídeo pode ser aplicado a estudantes de odontologia em qualquer fase da } \\
\text { graduação e pós-graduação }\end{array}$ & & & & & \\
\hline $\begin{array}{l}\text { 30. Tenho acesso ao material semelhante para o processo de ensino e } \\
\text { aprendizado da odontogênese. }\end{array}$ & & & & & \\
\hline 31. Considero que esse material didático tem um alto padrão de qualidade. & & & & & \\
\hline $\begin{array}{l}\text { 32. Esse material didático pode ser utilizado para formação de profissionais da } \\
\text { atenção primária. }\end{array}$ & & & & & \\
\hline 33. Esse material pode ser utilizado para orientar a comunidade. & & & & & \\
\hline 34. A linguagem utilizada permite a compreensão de estudantes de graduação. & & & & & \\
\hline 35. O vídeo pode ser utilizado por profissionais de outras áreas da saúde. & & & & & \\
\hline $\begin{array}{l}\text { 36. Ter contato com essa tecnologia durante a minha graduação teria facilitado } \\
\text { meu entendimento sobre o tema. }\end{array}$ & & & & & \\
\hline 37. Considero essa ferramenta útil para a prática docente. & & & & & \\
\hline 38. O uso desse material didático requer capacitação prévia do docente. & & & & & \\
\hline 39. Sinto-me apto a trabalhar com novas tecnologias educacionais. & & & & & \\
\hline
\end{tabular}


Dê uma nota de zero a dez para o material didático - Odontogênese:

\begin{tabular}{|l|l|l|l|l|l|l|l|l|l|l|l|}
\hline & 0 & 1 & 2 & 3 & 4 & 5 & 6 & 7 & 8 & 9 & 10 \\
\hline Conteúdo & & & & & & & & & & & \\
\hline Designer - imagens & & & & & & & & & & & \\
\hline Apresentação -layout & & & & & & & & & & & \\
\hline Computação gráfica 3D - animação & & & & & & & & & & & \\
\hline Som e Narração & & & & & & & & & & & \\
\hline Roteiro & & & & & & & & & & & \\
\hline
\end{tabular}

Dê uma nota geral de zero a dez para o material didático - Odontogênese:

\begin{tabular}{|l|l|l|l|l|l|l|l|l|l|l|}
\hline 0 & 1 & 2 & 3 & 4 & 5 & 6 & 7 & 8 & 9 & 10 \\
\hline
\end{tabular}

Qual a probabilidade de zero a dez de você vir a utilizar esse material na sua prática docente, sendo zero nenhuma probabilidade e dez $100 \%$ de probabilidade?

\begin{tabular}{|l|l|l|l|l|l|l|l|l|l|l|}
\hline 0 & 1 & 2 & 3 & 4 & 5 & 6 & 7 & 8 & 9 & 10 \\
\hline
\end{tabular}

Complete o perfil de forças e fraquezas do material didático - Odontogênse

\begin{tabular}{|c|c|}
\hline Forças & Fraquezas \\
\hline & \\
\hline & \\
\hline & \\
\hline & \\
\hline & \\
\hline
\end{tabular}

Quais são as suas sugestões para o aprimoramento desse material? 